\title{
A BASE DO GOLPE: A NOVA COLONIZAÇÃO PELA CAPTURA DA SUBJETIVIDADE.
}

\author{
LA BASE DU BEAT: LA NOUVELLE COLONISATION DE LA CAPTURE DE LA \\ SUBJECTIVITÉ.
}

\section{THE BASIS OF THE BEAT: THE NEW COLONIZATION FOR THE CAPTURE OF SUBJECTIVITY.}

DOI: http://dx.doi.org/10.9771/gmed.v11i1.30693

\begin{abstract}
Marcelo Lira Silva ${ }^{1}$
Resumo: Objetiva-se, com este ensaio, desenvolver uma análise do processo de tramitação e aprovação da Base Nacional Comum Curricular (BNCC), na medida em que tal Documento sintetiza um dado período histórico e caracteriza-se por ser expressão e símbolo de um Golpe de Estado que redesenhou, via Estado de Exceção, as instituições políticas brasileiras, inclusive, as educacionais. Deve-se destacar que a BNCC representa a objetivação e exteriorização, tanto em sua forma, quanto em seu conteúdo, dos princípios e diretrizes jurídico-políticos, aprovados pela Lei no 13.415, de 16 de fevereiro de 2017, e ideologicamente denominada de Reforma do Ensino Médio. Tratase, portanto, de dois Documentos Institucionais que alteraram profundamente a concepção administrativoorganizativa e pedagógica das instituições político-educacionais. Nesse sentido, buscar-se-á desenvolver uma análise dos Documentos Institucionais, cotejando-os com o processo histórico, a partir do qual emergiram enquanto novo arranjo político-institucional. A hipótese levantada é a de que tanto a BNCC, quanto a chamada Reforma do Ensino Médio, fazem parte da agenda contrarreformista, neoliberal-flexível, imposta de cima para baixo, por um Golpe de Estado no Brasil do século XXI, impondo, pela captura da subjetividade, um colonialismo de novo tipo. Nestes termos, doravante, denominar-se-á o processo em questão, sintetizado em tal Documento, de "A Base do Golpe". Assim, "A Base do Golpe" caracteriza-se por ser uma tentativa de apreensão e entendimento da particularidade histórica brasileira, como forma de construção de um diagnóstico de época, capaz de iluminar o Brasil do século XXI, que em seu segundo decênio passa por uma crise social profunda e aponta para tendências de neocolonialismo, de avanço da barbárie e deterioração das liberdades democráticas.
\end{abstract}

Palavras-chave: Reforma do Ensino Médio - BNCC - Golpe de Estado.

Résumé: L'objectif de cet essai est de développer une analyse du processus de traitement et d'approbation de la base commune des programmes nationaux (BNCC), dans la mesure où ce document résume une période historique donnée et se caractérise par le fait qu'il est l'expression et le symbole d'une Un coup d'État qui a redessiné, par le biais de State of Exception, les institutions politiques brésiliennes, y compris les institutions éducatives. Il convient de noter que le BNCC représente l'objectivation et l'externalisation, tant dans la forme que dans le contenu, des principes et directives juridico-politiques, approuvés par la loi n ${ }^{\circ} 13415$ du 16 février 2017, et appelée idéologiquement. Lycée. Ce sont donc deux documents institutionnels qui ont profondément modifié la conception administrative, organisationnelle et pédagogique des institutions politico-éducatives. Dans ce sens, nous chercherons à développer une analyse des documents institutionnels, en les comparant avec le processus historique, à partir duquel ils ont émergé en tant que nouvel arrangement politico-institutionnel. L'hypothèse avancée est que la BNCC et la soi-disant réforme du lycée font partie du programme néo-libéral et flexible de contre-réforme réformiste, imposé de fond en comble par un coup d'État au Brésil du XXIe siècle, imposant de subjectivité, un colonialisme d'un nouveau type. En ces termes, on appellera dorénavant le processus en question, résumé dans un tel document, "La base du coup d'Etat". Ainsi, "La base du coup d'Etat" se caractérise par une tentative d'appréhension et de compréhension de la particularité historique brésilienne, en tant que moyen d'établir un diagnostic de l'époque, capable d'éclairer le Brésil au XXIe siècle, qui passe par la une crise sociale profonde et des tendances néo-coloniales, de la promotion de la barbarie et de la dégradation des libertés démocratiques. 
Mots-clés: Réforme des lycées - BNCC - Coup d'État.

Abstract: The objective of this essay is to develop an analysis of the process of processing and approval of the National Curricular Common Base (BNCC), insofar as this document summarizes a given historical period and is characterized by being an expression and symbol of a State that redesigned, through State of Exception, the Brazilian political institutions, including, the educational ones. It should be noted that the BNCC represents the objectification and externalization, both in form and content, of legal-political principles and guidelines, approved by Law 13,415 of February 16, 2017, and ideologically called High school. It is, therefore, two Institutional Documents that profoundly altered the administrative-organizational and pedagogical conception of political-educational institutions. In this sense, we will seek to develop an analysis of the Institutional Documents, comparing them with the historical process, from which they emerged as a new political-institutional arrangement. The hypothesis raised is that both the BNCC and the so-called High School Reform are part of the neo-liberal, flexible counter-reformist agenda, imposed from top to bottom, by a coup d'etat in Brazil of the 21 st century, imposing, by the capture of subjectivity, a colonialism of a new type. In these terms, from now on, it will be called the process in question, summarized in such document, "The Base of the Coup". Thus, "The Basis of the Coup" is characterized as an attempt to apprehend and understand the Brazilian historical particularity, as a way of constructing a diagnosis of the era, capable of illuminating Brazil in the twenty-first century, which in its second decade goes through a deep social crisis and points to tendencies of neocolonialism, of advancement of barbarism and deterioration of democratic freedoms.

Keywords: High School Reform - BNCC - Coup d'État.

\section{Introdução}

O diagnostico de época do tempo presente indica que tanto o Currículo forjado a partir da chamada Reforma do Ensino Médio, conduzida via Medida Provisória² e aprovada sob a forma da Lei n ${ }^{\circ} 13.415$, de 16 de fevereiro de 20173; quanto o processo constitutivo de tramitação e aprovação das Bases Nacional Comum Curricular (BNCC) ${ }^{4}$ - Ensino Infantil/Fundamental de 2017/Ensino Médio de 2018 -, bem como o processo de recomposição do Conselho Nacional de Educação (CNE) e a aprovação da Resolução $n^{\circ} 03$, de 21 de novembro de 2018, representam as determinações histórico-sociais de um novo ciclo de acumulação do capital na periferia capitalista, marcado pela luta de classes aberta e pela extrema espoliação e precarização da classe trabalhadora, expressas em uma nova concepção de Escola, sintetizada em uma Matriz. Curricular enxuta, fragmentada e esvaziada, voltada a formar contingentes cada vez maiores para um mercado de trabalho informal que necessita de um amplo exército industrial de reservas, para manter as altas taxas de lucro das grandes corporações do capital-imperialismo. Todavia, tal redesenho da estrutura jurídico-política do sistema educacional brasileiro só seria possível em um cenário de Golpe de Estado, no e a partir do qual o Estado de Exceção, na medida em que bloqueia toda e qualquer forma de participação e representação da classe trabalhadora, criaria as condições para a aprovação atípica e subterrânea de uma legislação antidemocrática e antipopular. Assim, no âmbito do sistema educacional, a BNCC caracteriza-se por ser a síntese desse processo, investindo-se e representando a cultura política autocrática forjada pelas instituições políticas brasileiras, na e a partir da qual se estruturou e se estrutura o novo sistema educacional brasileiro, gestado e partejado por um Golpe de Estado. A esse processo denominar-se a Base do Golpe.

\section{Parte I: Tempos de mercadoria programada: a subjetividade mutilada do sistema educacional neoliberal-flexível extremado.}

Estruturalmente, o Brasil é um país de capitalismo tardio, dependente e associado ao capitalimperialismo. Isso significa dizer que o Brasil está integrado ao sistema capitalista, todavia, na condição de 
associado-subalterno, localizado na periferia. As instituições educacionais não são entidades metafisicas que pairam sobre a realidade, pelo contrário, possuem uma base material, a partir da qual se desenvolvem, se articulam, se dinamizam e se movimentam, como forma de objetivar e exteriorizar sua função social. Tratase, portanto, de entender a base objetiva e subjetiva, na e a partir da qual se constituem os sistemas educacionais, como forma de romper com a ideologia salvacionista da educação, difundida como neutra, técnica, despida e apartada da política econômica e das decisões políticas do bloco no poder, em um dado Estado nacional. Isso significa dizer que os sistemas educacionais não são estruturados em atos de vontade individual (dedicação do aluno e/ou professor e/ou coordenação/direção) ou em relações bilaterais (professor-aluno), pelo contrário, caracterizam-se por ser parte importante de uma determinada política econômica, que, por um lado, necessita criar as condições objetivas para sua materialização, por outro, necessita construir o consenso acerca dela, capturando e/ou formando a subjetividade dos indivíduos de um determinado tempo histórico, de acordo com as necessidades societais do espírito da época.

A ideologia da globalização instituiu um conjunto de mecanismos de controle e coesão social, no âmbito dos Estados nacionais, via Organismos Multilaterais, como forma de controlar e definir as diretrizes políticas das instituições educacionais da periferia capitalista. Em um cenário de crise estrutural do capital, o controle autocrático das instituições políticas é de fundamental importância, na medida em que a crise acirra os conflitos, gera convulsões sociais constantes e acabam, de forma indireta, constituindo um terreno de luta de classes aberta. Ora, a divisão internacional do trabalho, no âmbito da ideologia da globalização, estruturou um tipo particular de geopolítica, ao qual os sistemas educacionais nacionais capitalistas encontram-se submetidos. Tratar-se-ia, por um lado, da estruturação de sistemas educacionais mercantilizados, em todas as suas esferas; e, por outro, pela estruturação de sistemas educacionais competitivos, hierarquizados e fundamentados em um tipo de matriz curricular reificada.

Nesse sentido, o Currículo passa a ser definido a partir da posição geopolítica que os Estados Nacionais ocupam, bem como pela posição que as instituições educacionais ocupam no sistema educacional dos Estados Nacionais. Ou seja, trata-se da institucionalização de processos de competição e hierarquização de ordem interna e externa que se retroalimentam e se consubstanciam, como forma de ranquear e intensificar os processos de seleção, em todos os níveis e modalidades de ensino. Isso implica em dizer que os sistemas educacionais passam a ser estruturados a partir da relação centro-periferia, tanto no interior dos Estados Nacionais, quanto na relação entre os Estados Nacionais, constituindo-se ilhas de excelências competitivas e hierarquizadas, por um lado; e sistemas periféricos, internos e externos, precários, aligeirados e desumanizados, por outro. Trata-se, portanto, de um duplo processo de periferização: a) intensificação da periferização dos Estados nacionais dependentes e associados ao capital-imperialismo; e, b) intensificação da periferização das periferias, forjando-se periferias dentro das periferias.

A ideologia da globalização está estruturada no neoliberalismo-flexível, que pode ser definido enquanto determinação objetiva e subjetiva de um novo ciclo de acumulação, em um cenário de crise estrutural do capital e de objetivação plena do capital-imperialismo. Assim, por um lado, opera pela via da colonização dos Estados nacionais, apropriando-se de sua estrutura jurídico-política, de seu orçamento e transformando suas principais atividades políticas em negócios altamente rentáveis. Trata-se de um cálculo 
que diminui os riscos do grande capital, na medida em que o Estado passa a ser o fiador dos negócios; e, por outro, constitui mecanismos e instituições produtoras de uma formação distorcida da subjetividade, a partir das quais naturaliza os indivíduos e os converte em competidores empresariais.

Nesse cenário, a escola capitalista neoliberal-flexível estrutura um tipo de Currículo Instrumental, forjado a partir da formação de uma authoritarian personality (ADORNO, 1995), na e a partir da qual a formação desvincula-se do processo de humanização e passa a se submeter única e exclusivamente ao pragmatismo técnico e utilitarista da cotidianidade. Assim, para se entender os fundamentos do Currículo torna-se necessário realizar o diagnóstico do tempo presente. Se uma das características da consciência coisificada é manter-se restrita a si mesma, torna-se necessário compreender o Currículo enquanto uma determinação histórico-social, a partir do qual pode-se superar a reificação imposta pela pragmática utilitarista do cotidiano ou reafirmá-la.

Trata-se de compreender e analisar os sentidos e significados do Currículo, enquanto expressão e representação da luta de classes no processo formativo. Assim, a concepção, a estrutura formal e o conteúdo da Matriz Curricular, por um lado, expressa uma determinada concepção de sociedade; e, por outro, expressa o processo formativo necessário à constituição de uma determinada forma de subjetividade. Tratar-se-ia de saber: Qual seria a forma e o conteúdo de determinado Currículo? Nesse sentido, para se compreender os sentidos e significados do Currículo, tornar-se-ia necessário compreender a particularidade histórica do processo formativo, como forma de se entender o processo de formação da subjetividade, bem como sua captura, quando se encontra presente um processo autocrático de colonização do processo formativo, via mercado.

O Currículo não é e nem pode ser apreendido enquanto uma abstração aleatória de disciplinas e conteúdos, mas enquanto uma determinação sociohistórica de dada particularidade societal. Portanto, discutir Currículo no Brasil, implica em compreender como suas particularidades político-econômicas e sociohistóricas são suprassumidas na Matriz Curricular de determinado período histórico, bem como qual seria a correlação de forças expressas no interior da Matriz Curricular, na medida em que os sistemas educacionais são expressão objetiva e subjetiva da luta de classes, sendo a Matriz Curricular o momento de objetivação e exteriorização da correlação de forças, presente em dado tempo histórico. A Matriz Curricular caracteriza-se por ser mais ou menos progressista, mais ou menos emancipatória, na medida em que a classe trabalhadora consiga impor seu programa societal, obrigando as classes dominantes a fazer concessões de diversas ordens, presentes na política educacional adotada pelo Estado, a partir da qual se altera: a) a concepção de administração e organização da Escola; b) a política de formação de professores; c) a concepção pedagógica; d) o Currículo; e) a relação professor-aluno; f) a concepção de avaliação; e, g) os processos de acesso, permanência e êxito. Todos os processos mencionados são mais ou menos democráticos, mais ou menos progressistas, mais ou menos emancipatórios, de acordo com a correlação de forças presente em dado tempo histórico. Não são, em absoluto, resultado de uma vontade individual maligna ou benigna, genial ou medíocre, técnica ou política, como ideologicamente tenta-se difundir no âmbito do senso comum cotidiano e, por vezes, acadêmico. Compreender a Escola a partir de parâmetros maniqueístas, de talhe salvacionista, converteu-se em uma das principais ideologias da classe dominante 
brasileira. O que a Escola é e/ou poderia ser, depende fundamentalmente da capacidade organizativa e de pressão, da classe social que vive as agruras e as misérias, materiais e espirituais, da sociedade capitalista.

Assim, toda Matriz Curricular é, por excelência, resultado da luta de classes de determinado ciclo histórico, emergindo enquanto síntese dos projetos de sociedade em disputa. Ao sintetizar o Projeto Político Pedagógico de um Curso e/ou de uma Escola, a Matriz Curricular traduz o espírito da época, bem como a correlação de forças presente em dado ciclo histórico. Portanto, sua eficácia está relacionada à política educacional do Estado nacional; a forma de administração e organização do espaço escolar; a concepção de avaliação; aos processos de ingresso, permanência e êxito; e, a política de formação de professores. Nesse sentido, discutir, analisar e avaliar o processo formativo de ensino-aprendizagem, a partir da relação professor-aluno caracteriza-se por ser um falseamento da realidade, visto que tal relação é o último momento do processo de planejamento e organização da formação, carregando consigo todas as variáveis anteriores. Trata-se do momento de execução do processo, sendo sua manifestação fenomênica, por excelência. Ora, trata-se então de saber: quais são os sujeitos que discutem e deliberam acerca do planejamento, organização e administração do processo formativo? Se professores, alunos e a comunidade não participam enquanto sujeitos ativos e autônomos de tal processo, as relações professor-aluno e escola-comunidade, só poderiam ser de tipo reificada. No âmbito da luta pela consciência, a educação é definida como um valor universal abstrato e neutro. Todavia, o processo formativo encontra-se umbilicalmente ligado a humanização, portanto, a educação só é e só pode ser definida a partir do diagnóstico do tempo presente do espirito de época presente em dada formação societal, na qual a relação professor-aluno é mera manifestação fenomênica da política educacional.

Desde as primeiras discussões teóricas acerca do Currículo, na segunda metade do século XIX e, particularmente, de forma mais objetiva e rigorosa, nas primeiras décadas do século XX, o Currículo emergiu enquanto cálculo racional e operacional de construção de consensos, acerca de um dado tipo de sociedade urbano-industrial que se expandia progressivamente, via revoluções industriais e reestruturações produtivas, a partir das quais se tornaria necessário difundir tipos específicos de técnicas de racionalização do trabalho, todavia, instituídas de forma inconsciente, a partir dos processos de socialização e interação, promovidos pelos sistemas educacionais. Nesse sentido, o Currículo, ao longo do século XX, tornou-se um instrumento cada vez mais objetivo e sofisticado de adequação social ao mundo do trabalho, por um lado; e, de reprodução de uma dada ordem societal, subjetivamente interiorizada, por outro, a partir da qual a consciência reificada dos sujeitos justificaria para si próprio, às diversas formas de dominação e reificação, instituídas na e pela sociedade capitalista. Assim, o processo de escolarização forja processos formativos inconscientes, a partir dos quais os sujeitos interiorizam, objetivam e exteriorização processos de coisificação de si e da própria subjetividade, que legitimam a dominação burguesa, de tal forma a naturalizá-la.

No último quartel do século XX, sob a pedagogia da hegemonia neoliberal-flexível, o Currículo adquiriu sua forma instrumental plena, constituindo-se em um Curriculo Instrumental, marcado pela fragmentação, coisificação da ciência e da técnica, que se descolam do processo de humanização e convertem-se em formas diretas e intencionais de dominação por excelência, como processo formativo de uma consciência coisificada, marcada pela reprodução de uma cotidianidade fascistizante e pelo bloqueio de 
processos formativos emancipatórios. Se no âmbito da política econômica, o neoliberalismo flexível necessita destruir toda e qualquer concepção de direitos (civis, políticos e sociais), para se efetivar e se reproduzir, enquanto forma objetiva e subjetiva de mercantilização da vida; no âmbito educacional, necessita desconstruir os processos formativos emancipatórios dos sujeitos, tanto no âmbito das instituições quanto da cotidianidade, instituindo-se processos agudos de formação de authoritarian personality e de regressão cultural (SILVA, 2014) $)^{5}$.

O Currículo Instrumental é um cálculo racional que interdita o pensamento, a reflexão e as possibilidades de desenvolvimento das potencialidades humanas e, portanto, representa a interdição do desenvolvimento da própria autonomia do sujeito. Se, por um lado, um dos valores mais elevados das revoluções burguesas encontra-se no marco da criação das condições objetivas e subjetivas de manifestação e desenvolvimento das liberdades individuais, mediante processos agudos e profundos de individuação; por outro, os processos de socialização e interação burgueses, inclusive no âmbito das instituições educacionais, na medida em que se distanciaram do legado do aufklärung, criaram mecanismos inconscientes de reificação dos próprios processos de individuação, de tal forma a homogeneizar e fazer do indivíduo uma mercadoria programada.

No âmbito do capitalismo contemporâneo, os processos de individuação são interditados, na medida em que os meios de comunicação os absorvem e os homogeneízam, transformando-os em mercadorias programadas, e, consequentemente, em manifestação de liberdade individual aparente. No âmbito dos avanços da robótica, da nanotecnologia e da internet, os processos de socialização e interação, foram absorvidos pelas redes sociais - formas reificadas de aprendizagens intuitivas -, na e a partir das quais se desenvolveu um elogio inconsciente à imediaticidade, expresso nas manifestações imediatas dos sentidos, bem como na impossibilidade de construção de mediações e reflexões autônomas dos processos de socialização e interação. Trata-se de uma quebra e de uma aceleração do tempo. O tempo fragmentado e acelerado impede toda e qualquer possibilidade de elaboração e recuperação da experiência formativa, restando em seu lugar, feixes de tempo (despidos de luz) e de percepção de si e da realidade: formas reificadas de simulacros dentro de simulacros. O fetichismo da técnica converteu-se em ideologia da tecnologia, na medida em que colonizou os processos formativos, de tal forma a bloquear as possibilidades de recuperação da experiência enquanto elaboração do processo formativo. Trata-se do desaparecimento do lampejo de indivíduo livre, esboçado pelo aufklärung, de tal forma a emergir em seu lugar a mercadoria programada, enquanto expressão da manifestação fenomênica de indivíduos livres. Todavia, nem são indivíduos, nem são livres.

O Curriculo Instrumental adquire sua forma e seu conteúdo pleno na Escola-empresa, na qual a mercantilização da vida coloniza o processo formativo e submete a Escola a lógica, a concepção e ao cálculo pragmático-instrumental da empresa, na qual a virtude encontra-se nos princípios de racionalidade instrumental, de eficiência e produtividade, advindos dos ritos e procedimentos de uma entidade mítica denominada mercado, para o qual o indivíduo é mera mercadoria programada. Trata-se de uma quadratura histórica na qual os princípios emancipatórios advindos das revoluções burguesas clássicas, como aqueles estruturados no aufklärung, necessitam ser destruídos, para que o novo ciclo de acumulação do capital se 
realize, sob a hegemonia neoliberal-flexível. Assim, o neoliberalismo é uma negação histórica do próprio liberalismo clássico, na medida em que enquanto o último instituiu processos emancipatórios de emancipação política dos indivíduos, o primeiro instituiu processos de desemancipação e de barbárie, destruindo, no limite, uma de suas principais virtudes: as liberdades individuais.

No limite, a Escola-empresa caracteriza-se por ser a expressão objetiva e subjetiva dos processos de reestruturação produtiva fabril, de tal forma a implementar um tipo de Currículo Instrumental, flexível e adaptável a dinâmica dos ciclos de acumulação do capital. Assim, o Currículo Instrumental expressa um tipo particular de sistema produtivo, no e a partir do qual objetiva-se produzir em massa tipos de mercadorias programadas, mediante processos produtivos homogeneizados, ora verticalizados, ora horizontalizados, a depender do ciclo de acumulação do capital. O processo produtivo, aparentemente interno à indústria, extrapola a indústria e passa a se impor e a colonizar o conjunto das relações sociais. No âmbito da Escolaempresa, estrutura-se um tipo de trabalho parcelar e fragmentado, no qual, tanto o aluno, quanto o professor, são meros repetidores de ações alienadas e alienantes, posicionando-os enquanto peças de funcionamento da maquinaria, que passaria a programar a repetição e a delimitar, a partir de um cronômetro, o tempo e o ritmo de suas ações. Todavia, diferentemente da lógica interna da indústria, a Escola-empresa não é capaz de extrair mais-valia, todavia, transforma, todos os sujeitos envolvidos no processo, em mercadorias programadas, na medida em que opera pela captura da subjetividade. A Escola-empresa caracteriza-se por ser uma mescla da produção em série fordista com o cronômetro taylorista, instituindo de maneira rígida a separação entre elaboração e execução, como uma espécie de trabalho rotinizado, programado e fechado para a criatividade.

Assim, a Escola-empresa encontra sua determinação plena sob a égide do processo produtivo do toyotismo-ohnismo, na medida em que instituiu processos produtivos autocráticos, no e a partir dos quais a produção de mercadorias programadas caracteriza-se por ser aparentemente variada e heterogênea, na medida em que se encontra umbilicalmente articulada a um tipo particular de demanda. Trata-se de um Currículo Instrumental que atende a necessidades de consumo imediatas e aparentemente individualizadas, portanto, estruturado no trabalho informal. Diferentemente do Currículo Instrumental do taylorismo-fordismo, que se fundamentava na produção em série e de massa, no Currículo Instrumental de tipo toyotismo-ohnismo, opera-se pela constituição de equippes polivalentes, que passariam a assumir uma multivariedade de funções, de tal forma a romper com a lógica parcelar do fordismo, que condicionava o trabalhador ao ritmo e ao tempo de uma máquina específica.

O novo padrão produtivo de acumulação do capital exige flexibilidade, tanto da estrutura do sistema produtivo e da força de trabalho empenhada, quanto do próprio processo de formação da subjetividade. Trata-se da implementação do princípio just in time na própria estrutura da Matriz. Curricular, no e a partir do qual a maximização da produtividade deve ocorrer em um menor tempo possível. Implementa-se o sistema kanban na Escola-empresa, via Matriz. Curricular flexivel, na medida em que programa-se um conjunto de senhas de comando, como forma de reposição rápida de peças e, ao mesmo tempo, de redução do estoque a necessidades imediatas. O princípio fordista de constituição de grandes estoques homogêneos fora convertido em um princípio de toyotismo-ohismo de estoques necessários e heterogêneos a demandas individualizadas e imediatas. O rígido complexo de verticalização toyotista-fordista, fora substituído pela horizontalização do complexo produtivo toyotista, que passara a produzir o mínimo necessário em suas Escolas-empresas - teoria do foco-, de tal forma a terceirizar 
a maior parte da produção. Trata-se de um novo processo de reestruturação da Escola-empresa, na qual buscarse-ia incrementar, sem limites, o trabalho morto corporificado no maquinário técnico-científico, ou seja, em um mercado rotinizado, programado e flexível, a ser expandido e consolidado (o uso das novas tecnologias, tanto nos processos de administração e organização do espaço escolar; quanto no processo formativo, via Educação à Distância). Implementa-se um processo agudo de liofilização organizacional do processo formativo, no qual reduz-se drasticamente o trabalho vivo e amplia-se o trabalho morto. Trata-se da Escola-empresa enxuta, fragmentada, heterogênea, como forma de atender a demanda do novo ciclo de acumulação do capital, fundamentado na ampliação progressiva do trabalho informal e na obsolescência programada das profissões e atividades laborais.

\section{Parte II: A Base do Golpe: a contrarreforma do sistema educacional brasileiro.}

A análise de Documentos Institucionais, particularmente de legislações específicas, no caso particular, a educacional, exige do pesquisador o esforço de reconstrução do processo histórico, como forma de entender a legislação vigente enquanto expressão e manifestação da forma/conteúdo da luta de classes de dado período histórico. Assim, toda legislação representa a correlação de forças existente em dada sociedade. Cotejar Documentos Institucionais, sem reconstruir o processo histórico, no e a partir do qual se deu seu processo de objetivação/exteriorização, significaria falsear a história, de tal forma a constituir uma análise reificada. Nesse sentido, a tentativa de buscar qualquer nível de entendimento acerca das instituições educacionais brasileiras do século XXI, exigiria de todo e qualquer pesquisador o esforço de entendimento dos processos constitutivo e de colapso da Nova República (1988-2016) (SILVA, 2017)6.

A definição da institucionalidade e a política educacional forjada no âmbito da Nova República, encontra-se inscrita em um ciclo de luta de classes (1986-1996), no e a partir do qual a correlação de forças se alterou, de tal forma que as concessões feitas as classes trabalhadoras foram rapidamente convertidas em avanço do capital sobre o trabalho. Assim, a LDBEN/1996 não pode ser entendida enquanto um ato de vontade e/ou desejo individual manifesto, mas enquanto representação da luta de classes e da correlação de forças entre as classes sociais no Brasil, no período de 1986 a 1996. Tratar-se-ia de um decênio, no qual a correlação de forças mudou drasticamente. As experiências de organizações autônomas da classe trabalhadora dos anos de 1980 pautavam-se pela grande politica, e colocavam na ordem do dia a necessidade de converteremse em organizadores sociais, como forma de se definir o programa necessário para a construção de uma sociedade de novo tipo. Portanto, o debate sobre a questão da educação encontra-se subsumido ao debate acerca da construção de um novo tipo de sociedade. Diferentemente do cenário dos anos de 1990, no qual as principais experiências de organizações autônomas da classe trabalhadora transitaram para o campo da pequena politica, declinaram do projeto de se tornarem organizadores sociais, passaram por um processo profundo de transformismo ativo e aderiram à parte da pauta neoliberal-flexível, em nome do pragmatismo políticoeleitoral. Tratar-se-ia de um processo complexo de alteração da correlação de forças entre as classes sociais, bem como no interior das frações de classes dominantes e trabalhadoras; ou seja, a visão maniqueísta do projeto democrático-popular em contraposição ao privatista-neoliberal, apresenta-se como equivocada, na medida 
em que, ao longo do decênio em questão, o democrático-popular se conciliou com o privatista-neoliberal, tanto na política de conciliação de classes de centro-direita do PSDB, quanto de centro-esquerda do PT $\left(\right.$ SILVA, 2017) ${ }^{7}$.

Nesse contexto, no campo da construção de uma proposta de política educacional da Sociedade Civil do Mundo do Trabalho, o FNDEP ocupa lugar central. Denominado, inicialmente, de Fórum da Educação na Constituinte em Defesa do Ensino Público e Gratuito, devido ao processo de redemocratização do país e a necessidade imperiosa de apresentação de um projeto político de educação, forjou-se no âmbito da Sociedade Civil do Mundo do Trabalho, o Fórum Nacional em Defesa da Escola Pública (FNDEP), composto incialmente por 15 entidades $^{8}$, e formalizado em 09 de abril de 1987, constituía-se enquanto organizaçãa relativamente autônoma da classe trabalhadora, adotando a fórmula política da Frente Única, como forma de aglutinar e definir seu programa e suas ações políticas. O FNDEP foi forjado por um conjunto de entidades acadêmico-científicas, sindicais e movimentos estudantis, tendo como ponto de partida a realização da Conferência Brasileira de Educação (CBE), no decorrer dos anos de 1980. Particularmente, a IV Conferência9 ${ }^{9}$, realizada em Goiânia, de 2 a 5 de setembro de 1986, adquiriu papel destacado, na medida em que foi organizada sob o tema Educação na Constituinte e se propôs a aprovar um Documento (denominado de Carta de Goiânia $^{10}$ ) que contivesse um Projeto de Educação para o país, presente em seus 21 princípios. O Documento em questão foi de fundamental importância e pautou as questões fundamentais acerca da educação brasileira, tanto no processo da Constituinte, quanto no decorrer dos anos de 1990. Todavia, o final dos anos de 1980 apontava para o refluxo dos vigorosos movimentos sociais e populares que pulularam no final dos anos de 1970 e obrigaram a adoção de um processo de distensão da ditadura civil-militar (19641985), alterando a correlação de forças em favor da pauta conservadora no país.

O debate e a necessidade acerca da criação de um conjunto de Documentos Institucionais, capazes de garantir o direito à educação a todos os brasileiros, encontra-se presente nas instituições políticas brasileiras, desde o processo de democratização do país. Com o influxo dos movimentos sociais e populares, advindos do final dos anos de 1970 e início dos anos de 1980, as classes dominantes foram obrigadas a fazer concessões de diversas ordens às classes trabalhadoras e demais classes subalternas, naquilo que diz respeito à garantia de direitos civis, políticos e sociais. Neste sentido, a Constituição de 1988, naquilo que diz respeito à definição da política educacional brasileira, aprovou um conjunto de princípios, a partir dos quais se poderia caminhar no sentido da universalização da Educação Básica e na garantia do direito à educação.

Art. 210. Serão fixados conteúdos mínimos para o ensino fundamental, de maneira a assegurar formação básica comum e respeito aos valores culturais e artísticos, nacionais e regionais. $\int 1^{\circ} \mathrm{O}$ ensino religioso, de matrícula facultativa, constituirá disciplina dos horários normais das escolas públicas de ensino fundamental. $₫ 2^{\circ} \mathrm{O}$ ensino fundamental regular será ministrado em língua portuguesa, assegurada às comunidades indígenas também a utilização de suas línguas maternas e processos próprios de aprendizagem ${ }^{11}$.

O artigo 210 da Constituição de 1988, apesar de sua importância política, restringiu-se a instituir a necessidade de criação de conteúdos mínimos para o Ensino Fundamental, omitindo-se sobre a questão do Ensino Infantil e Médio, partes constitutivas e fundamentais da Educação Básica no Brasil. Tratar-se-ia de uma limitação política acerca da concepção de Educação Básica. Apesar das limitações presentes na 
Constituição de 1988, naquilo que diz respeito a garantia ao direito à educação, pode-se observar, de forma germinal, a questão da necessidade de planejamento e organização de uma Base Nacional Comum Curricular (BNCC), capaz de garantir conteúdos mínimos, para todos os brasileiros, como forma de se universalizar e efetivar o direito à educação. Todavia, a questão que se colocava era a da criação de instrumentos jurídicopolíticos capazes de obrigar o Estado a assumir a responsabilidade pela educação de todos os brasileiros.

Tratar-se-ia de superar o processo autocrático de construção e aprovação da Lei no 4.024, de 20 de dezembro de $1961^{12}$, que estabelecia a primeira Lei de Diretrizes e Bases da Educação Nacional (LDBEN/1961) e trazia consigo os fundamentos do pacto social varguista, no qual o desenvolvimentismo figurava como uma de suas figuras centrais, bem como o varguismo, como forma de controlar e bloquear qualquer possibilidade de participação e representação política autônoma da classe trabalhadora e demais classes subalternas. Nesses termos, tratar-se-ia de uma LDBEN/1961 autocrática, tanto em seu processo constitutivo, quanto de aprovação. Podem-se observar três questões centrais na LDBEN/1961: a) a questão da desobrigação do Estado, em garantir o direito à educação a todos os brasileiros; b) a questão da garantia de oferecimento de educação pela iniciativa privada, com garantia de recursos e financiamento público; e, c) diretrizes conservadoras, voltadas ao atendimento de uma pauta moral-religiosa. A LDBEN/1961 previa que “art. $2^{\circ}$ A educação é direito de todos e será dada no lar e na escola. Parágrafo único. À família cabe escolher o gênero de educação que deve dar a seus filhos”. Em complemento ao artigo segundo, afirma-se:

Art. $3^{\circ} \mathrm{O}$ direito à educação é assegurado: I - pela obrigação do poder público e pela liberdade de iniciativa particular de ministrarem o ensino em todos os graus, na forma de lei em vigor; II - pela obrigação do Estado de fornecer recursos indispensáveis para que a família e, na falta desta, os demais membros da sociedade se desobriguem dos encargos da educação, quando provada a insuficiência de meios, de modo que sejam asseguradas iguais oportunidades a todos.

O debate educacional dos anos de 1980 e 1990 traz consigo todas as questões postas no âmbito da LDBEN/1961, como forma de superá-los política e pedagogicamente. Deve-se destacar que os processos de discussão, deliberação e homologação da Lei no 9.394, de 20 de dezembro de 199613, que instituiu a Lei de Diretrizes e Bases da Educação Nacional (LDBEN), foram marcados por um conjunto de contradições político-econômicas e socioculturais que faziam parte do contexto brasileiro, no período. Particularmente, deve-se destacar o processo de esgotamento do contrato social varguista, naquilo que diz respeito as ideologias do desenvolvimentismo e varguismo; bem como a recomposição de um bloco no poder, sob a liderança das frações de classes rentista-financista. Isso significa dizer que o contrato social da Nova República (1988-2016), apesar do conjunto de concessões feitas às classes trabalhadoras e demais classes subalternas, fora forjado a partir da ascensão de um novo bloco no poder, com preponderância de forças políticas neoliberais e, portanto, de redefinição pelo alto da autocracia burguesa institucionalizada, como forma de redesenhar e aprofundar o processo de associação, dependência e subordinação do Brasil ao capital-imperialismo. No âmbito do sistema educacional, o primeiro Documento Institucional da Nova República a reverberar os princípios político-econômicos e socioculturais do novo bloco no poder, fora a LDBEN/1996, na medida em que institucionalizou um processo de novo tipo de mercantilização da educação, tanto na Educação Básica, quanto Superior, bem como submeteu a política educacional brasileira a política econômica neoliberal- 
flexível, difundida pelos organismos multilaterais que passaram a intervir decisivamente na política educacional dos Estados nacionais da periferia capitalista, instituindo avaliações externas de larga escala de tipo pragmática-utilitarista, como forma de definir de forma indireta, tanto as matrizes curriculares, quanto as concepções pedagógicas, forjando um currículo oculto flexivel e reificado que passou a determinar o processo formativo.

Especificamente, a LDBEN/1996 começou a ser discutida em 1987 e influenciou profundamente no debate educacional da Constituinte. O Primeiro Projeto da LDBEN/1996 foi delineado por Demerval Saviani (1943 - ), e a partir de um conjunto de emendas realizadas a partir de amplas discussões no âmbito das entidades do FNDEP, fora apresentado à Câmara dos Deputados, sob a forma do Projeto de Lei no 1.258-A/1988, pelo Deputado Federal Jorge Hage (PSDB-BA). No processo de tramitação na Câmara, o Projeto de Lei foi acusado de corporativista e detalhista, pelo Ministro da Educação do Governo Collor (1990-1992), José Goldenberg (1928 - ), crítica absorvida e difundida pelo então senador Darcy Ribeiro (1922-1997). A longa tramitação nas diversas Comissões da Câmara dos Deputados acabou por alterar e desconfigurar profundamente o Projeto de Lei, na medida em que, em 1991, somavam-se 1.263 emendas ao PL. O projeto construído no âmbito das entidades que compunham o FNDEP fora desconfigurado. Todavia, apesar da mudança de correlação de forças, o PL foi aprovado em 13 de maio de 1993 no Plenário da Câmara Federal, a partir de um acordo suprapartidário, assumindo a forma de PL no 1.258-C/1993 e sendo encaminhado para o Senado e identificado como PL nº101/1993. Tratava-se de um projeto negociado que preservava elementos importantes do projeto inicial.

Nesse processo, o então senador pedetista Darcy Ribeiro (PDT-RJ), herdeiro do personalismo e da ideologia de conciliação de classes varguista, apresentou o Projeto de Lei nº7/1992 que estabelecia a Lei de Diretrizes e fixava as Bases da Educação Nacional, atropelando o processo de negociação e pactuação na Câmara dos Deputados, em torno do PL advindo das entidades do FNDEP. Tratava-se de projeto alternativo ao PL n¹01/1993, de tal forma a dificultar sua aprovação. Sob a relatoria do senador Cid Sabóia de Carvalho (PMDB/ CE), o PL nº101/1993, acabou sendo enterrado, a partir de manobras regimentais de diversas ordens que impediam sua tramitação e votação no Plenário, mesmo com sessão marcada, como foi o caso da sessão de 30 de janeiro de 1995, cancelada por falta de quórum.

A aliança PSDB/PFL elegeu e deu sustentação aos Governos de Fernando Henrique Cardoso (1995-2002), de tal forma a demarcar claramente os tempos de avanço da agenda neoliberal-flexível extremada no Brasil, inclusive no campo da educação. Em 1995, Darcy Ribeiro apresentou um novo substituto, resultado de suas negociações com o então Ministro da Educação, Paulo Renato Costa Souza (PSDB). O substituo Darcy Ribeiro voltou a Câmara, fora relatado por José Jorge (PFL-PE) e sancionado pelo então presidente da república, sem alterações.

Os ideólogos da LDBEN/1996, a apresentavam enquanto representação da modernidade, ou seja, uma lei moderna, contraposta a propositura do Projeto de Lei Jorge Hage, caracterizado como arcaico e corporativista. A LDBEN/1996 aprovada, fora forjada nos marcos do neoliberalismo-flexível extremado, portanto, assumiu a flexibilidade enquanto questão central, de tal forma a desobrigar o Estado a assumir as responsabilidades necessárias à construção de um sistema de ensino público, universal, gratuito, laico e de 
qualidade. Ao mesmo tempo, a lei incorporou esvaziando parte das bandeiras reivindicatórias do movimento educacional dos anos de 1980, particularmente: a) a concepção de capacitação de professores foi traduzida como profissionalização; b) a participação da Sociedade Civil, como articulação unilateral com empresários e ONGs; c) a descentralização, com desconcentração de responsabilidade do Estado; d) a autonomia, como liberdade de captação de recursos no setor privado; e) a igualdade, com equidade; f) a concepção de cidadania crítica, com cidadania produtiva; g) a formação do cidadão, com atendimento ao cliente; h) a melhoria da qualidade, com adequação ao mercado; e, por fim, i) o aluno foi transformado em cliente/consumidor (SHIROMA, 2011).

Ora, certamente, a Lei n 9.394, de 20 de dezembro de 1996, que instituiu a Lei de Diretrizes e Bases da Educação Nacional (LDBEN) não respondeu aos anseios da classe trabalhadora, todavia, mesmo com seu caráter autocrático de caráter neoliberal-flexível extremado, definiu e demarcou princípios e diretrizes importantes para se entender o sistema educacional brasileiro contemporâneo. Dentre os avanços, pode-se observar a definição de educação escolar presente no art. 21. A educação escolar compõe-se de: $I$ educação básica, formada pela educação infantil, ensino fundamental e ensino médio. Tratar-se-ia de um entendimento e definição de Educação Básica complexa e, politicamente, avançada, em relação ao artigo 210 da Constituição, na medida em que se deveria definir uma política educacional geral, atentando-se para as particularidades de todas as etapas da Educação Básica. Em consonância com a definição acima mencionada, lê-se:

Art. 26. Os currículos da educação infantil, do ensino fundamental e do ensino médio devem ter base nacional comum, a ser complementada, em cada sistema de ensino e em cada estabelecimento escolar, por uma parte diversificada, exigida pelas características regionais e locais da sociedade, da cultura, da economia e dos educandos. (Redação dada pela Lei no 12.796 , de 2013) ${ }^{14}$.

Em um país com desigualdades regionais profundas, como é o caso do Brasil, torna-se importante que os Documentos Institucionais afirmem o compromisso e a responsabilidade do Estado em garantir o direito à educação, bem como sua universalização. Nesse sentido, o estabelecimento e a definição de uma BNCC pactuada nacionalmente, tornar-se-ia de fundamental importância, para a efetivação e garantia do direito à educação. Assim como a LDBEN/1996, o art.14 da Resolução CNE/CEB nº 4, de 13 de julho de 201015, que definiu as Diretrizes Curriculares Nacionais Gerais para a Educação Básica, abordou a necessidade de construção de uma BNCC, em termos mais avançados, tomando em conta a complexidade do sistema educacional, bem como da diversidade étnica brasileira:

A base nacional comum na Educação Básica constitui-se de conhecimentos, saberes e valores produzidos culturalmente, expressos nas políticas públicas e gerados nas instituições produtoras do conhecimento científico e tecnológico; no mundo do trabalho; no desenvolvimento das linguagens; nas atividades desportivas e corporais; na produção artística; nas formas diversas de exercício da cidadania; e nos movimentos sociais. $\int 1^{\circ}$ Integram a base nacional comum nacional: a) a Língua Portuguesa; b) a Matemática; c) o conhecimento do mundo físico, natural, da realidade social e política, especialmente do Brasil, incluindo-se o estudo da História e das Culturas Afro-Brasileira e Indígena, d) a Arte, em suas diferentes formas de expressão, incluindo-se a música; e) a Educação Física; f) o Ensino Religioso. \ $2^{\circ}$ Tais componentes curriculares são organizados pelos sistemas educativos, em forma de áreas de conhecimento, disciplinas, eixos temáticos, preservando-se a especificidade dos diferentes campos do conhecimento, por meio dos 
quais se desenvolvem as habilidades indispensáveis ao exercício da cidadania, em ritmo compatível com as etapas do desenvolvimento integral do cidadão. $\int 3^{\circ} \mathrm{A}$ base nacional comum e a parte diversificada não podem se constituir em dois blocos distintos, com disciplinas específicas para cada uma dessas partes, mas devem ser organicamente planejadas e geridas de tal modo que as tecnologias de informação e comunicação perpassem transversalmente a proposta curricular, desde a Educação Infantil até o Ensino Médio, imprimindo direção aos projetos político-pedagógicos.

Apesar dos avanços, manteve-se o ensino religioso, como um dos escombros advindos de um Estado autocrático, incapaz de se constituir de forma laica e garantir a liberdade religiosa no conjunto de suas instituições políticas. Não por um acaso, os escombros anti-laicidade retornam na BNCC, institucionalizando um ensino de tipo confessional. Os lobistas do complexo fundamentalismo religioso brasileiro, que mistura fé, política e mercado, utilizaram-se do falso e distorcido argumento de que a decisão do Supremo Tribunal Federal, acerca Ação Direta de Inconstitucionalidade 443916, sobre o ensino religioso nas escolas públicas, garantia a sua inserção na BNCC, mesmo quando com conteúdos voltados a uma religião específica.

A necessidade de se instituir e implementar uma Base Nacional Comum Curricular (BNCC), vinha sendo debatida por diversas organizações da Sociedade Civil do mundo do trabalho, com a finalidade de regulamentar, instituir e assegurar o direito à educação a todos os brasileiros. Portanto, não se trata de negar a necessidade e importância de criação e implementação de uma BNCC, mas de discutir a concepção, os fundamentos e a função social de tal Documento. Ora, trata-se de saber, se o Documento em questão caracteriza-se por ser emancipatório ou desemancipatório; democrático ou autocrático; universalista ou restritivo e limitador.

Já no Plano Nacional de Educação, regulamentado pela Lei no 13.005, de 25 de junho de 201417, encontram-se as seguintes preocupações, naquilo que diz respeito ao planejamento e organização do sistema educacional brasileiro, com vistas a garantia do direito à educação e sua universalização:

Meta 1: universalizar, até 2016, a educação infantil na pré-escola para as crianças de 4 (quatro) a 5 (cinco) anos de idade e ampliar a oferta de educação infantil em creches de forma a atender, no mínimo, $50 \%$ (cinquenta por cento) das crianças de até 3 (três) anos até o final da vigência deste PNE. [...] Meta 2: universalizar o ensino fundamental de 9 (nove) anos para toda a população de 6 (seis) a 14 (quatorze) anos e garantir que pelo menos 95\% (noventa e cinco por cento) dos alunos concluam essa etapa na idade recomendada, até o último ano de vigência deste PNE. [...] Meta 3: universalizar, até 2016, o atendimento escolar para toda a população de 15 (quinze) a 17 (dezessete) anos e elevar, até o final do período de vigência deste PNE, a taxa líquida de matrículas no ensino médio para 85\% (oitenta e cinco por cento). [...] Meta 7: fomentar a qualidade da educação básica em todas as etapas e modalidades, com melhoria do fluxo escolar e da aprendizagem de modo a atingir as seguintes médias nacionais para o Ideb.

Deve-se destacar que o processo de construção, tramitação da BNCC se deu em um ciclo conjuntural (2013-2018) de crise social profunda e de imposição de um conjunto de derrotas a classe trabalhadora, de tal forma que, no âmbito da educação, passou pelo Ministério da Educação seis ministros da educação, durante os Governos Dilma Rousseff (2011-2016: a) Fernando Haddad (01 de janeiro de 2011 a 23 de janeiro de 2012); b) Aloizio Mercadante (24 de janeiro de 2012 a 02 de fevereiro de 2014); c) José Henrique Paim (03 de fevereiro de 2014 a 01 de janeiro de 2015); d) Cid Gomes (01 de janeiro de 2015 a 18 de março de 2015); e) Luiz Claudio Costa (interino, de 18 de março de 2015 a 06 de abril de 2015); f) Renato 
Janine Ribeiro (06 de abril de 2015 a 01 de outubro de 2015); e, g) Aloizio Mercadante (02 de outubro de 2015 a 12 de maio de 2016); e, dois, durante o Governo provisório de exceção de Michel Temer (20162018): a) Mendonça Filho (12 de maio de 2016 a 06 de abril de 2018); e, b) Rossieli Soares (06 de abril de 2018 a 31 de dezembro de 2018). Deve-se destacar que a presidente eleita havia apenas sido afastada do cargo, para que o chamado impeachment fosse julgado, e o Governo provisório de exceção de Michel Temer (MDB-PSDB-DEM) agia como governo efetivo fosse. No âmbito da educação, coube a Gestão Mendonça Filho (DEM)/Maria Helena Guimarães de Castro (PSDB) conduzir o processo autocrático de contrarreforma do sistema educacional brasileiro.

Em meados de 2015, em meio a crise social pela qual o país passava e o Golpe de Estado em marcha, o MEC, comandado pelo então Ministro da Educação Renato Janine Ribeiro, instituiu a Comissão de Especialistas para a Elaboração da Proposta da Base Nacional Comum Curricular, mediante emissão da Portaria n ${ }^{\circ}$ 592, de 17 de junho de 2015, com as participações do Conselho Nacional de Secretários de Educação - CONSED e da União Nacional dos Dirigentes Municipais de Educação Undime. Em setembro do mesmo ano, o MEC publicou a primeira versão da BNCC ${ }^{18}$, redigida pela comissão nomeada, submetendo-a, logo em seguida, a um processo de consulta pública online, do qual teve como resultado mais de 12 milhões de contribuições. Em maio de 2016, sob o comando de Aloizio Mercadante, o MEC apresentou a segunda versão da BNCC ${ }^{19}$. No caso, o Consed e a Undine passaram a organizar seminários por todo o país, como forma de debater a questão e colher novas contribuições. Tratarse-ia de uma das últimas ações do inexistente segundo Governo Dilma Rousseff (2015-6), na medida em que em 31 de agosto de 2016, o Senado, com a anuência do STF, votou o impeachment de Dilma Rousseff, consumou o Golpe de Estado e instituiu o Governo provisório de exceção de Michel Temer (MDB-PSDBDEM). Poucas semanas depois, o Governo Temer emitia a Medida Provisória n ${ }^{\circ} 746$, de 22 de setembro de 2016, redefinindo de forma autocrática todo o sistema educacional brasileiro. A Medida Provisória redefiniu todos os parâmetros e discussões acerca da concepção de BNCC a ser adotada, de tal forma a definir um Documento antidemocrático e antipopular, em todos os seus aspectos.

Com o Golpe de Estado de tipo Parlamentar-Judicial-Midiático de 2016, a condução da BNCC se deu de forma autocrática, sob o comando da Gestão Mendonça Filho/Maria Helena Guimarães de Castro. No caso, o Ministro emitiu a Portaria n ${ }^{\circ}$ 790, de 27 de julho de 2016, instituindo o Comitê Gestor da Base Nacional Curricular Comum e Reforma do Ensino Médio ${ }^{20}$, delegando plenos poderes à Maria Helena Guimarães de Castro, para conduzir a contrarreforma da educação.

O MINISTRO DE ESTADO DA EDUCAÇÃO, no uso das atribuições que lhe confere o art. 87, parágrafo único, inciso II, da Constituição, e tendo em vista o disposto no art. 210 da Constituição e na Lei no 9.394, de 20 de dezembro de 1996, resolve: Art. 1o Fica instituído o Comitê Gestor para acompanhar o processo de discussão da segunda versão preliminar da Base Nacional Curricular Comum - BNCC, encaminhar sua proposta final e propor subsídios para a reforma do Ensino Médio. Art. 2o A versão da BNCC, a ser encaminhada ao Conselho Nacional de Educação - CNE, deverá definir o conjunto de conhecimentos e habilidades que os alunos devem adquirir e desenvolver em cada etapa de ensino e em cada ano de escolaridade. Parágrafo único. O estabelecido na BNCC deverá servir de guia de orientação para os sistemas e redes de ensino desenvolverem os seus próprios currículos. Art. 3o A proposta de reforma do Ensino Médio terá por diretriz a diversificação da sua oferta, possibilitando aos jovens diferentes percursos 
acadêmicos e profissionalizantes de formação. Art. 4o O Comitê Gestor será constituído pela Secretaria Executiva do Ministério da Educação - MEC, que o presidirá, pelo Secretário de Educação Básica, que será o seu Secretário-Executivo, e pelos titulares e suplentes dos seguintes órgãos e entidades vinculadas ao MEC: I - Secretaria de Educação Continuada, Alfabetização, Diversidade e Inclusão - SECADI; II - Secretaria de Educação Profissional e Tecnológica - SETEC; III - Secretaria de Educação Superior SESu; IV - Secretaria de Articulação dos Sistemas de Ensino - SASE; e V - Instituto Nacional de Estudos e Pesquisas Educacionais Anísio Teixeira - INEP. \1o Os suplentes serão indicados pelos titulares dos órgãos e entidades referidos nos incisos I, II, III, IV e V à Presidência do Comitê Gestor e nomeados por meio de instrumento específico. \2o A participação no Comitê Gestor não será remunerada; seu exercício será considerado serviço público relevante, e as atividades nele desempenhadas serão feitas sem prejuízo daquelas decorrentes dos respectivos cargos e função. Art. 5o Compete ao Comitê Gestor: I - acompanhar os debates sobre o documento preliminar da BNCC a serem promovidos nas unidades da Federação durante os meses de julho e agosto de 2016; II convidar especialistas para discutirem temas específicos da proposta em discussão da BNCC e sugerir alternativas para a reforma do Ensino Médio; III - propor definições, orientações e diretrizes para a elaboração da versão final e implementação da BNCC e de reforma do Ensino Médio; IV - estabelecer cronograma de trabalho; V - indicar especialistas para redigir a versão final da BNCC; e VI - estabelecer orientações para a implantação gradativa da BNCC pelas redes de ensino públicas e privadas. Art. 6o As deliberações do Comitê Gestor serão publicadas por meio de resoluções assinadas pelo Presidente. Art. 7o Esta Portaria entra em vigor na data de sua publicação.

A constituição do Comitê Gestor representou a concentração e centralização de poderes na Secretaria Executiva do Ministério da Educação, no caso, comandado por Maria Helena Guimarães de Castro, de tal forma a romper com a concepção de democracia participativa, adotada até então. Tratar-se-ia de uma ruptura de concepção e de método de discussão e deliberação, de tal forma a predominar o caráter autocrático, antidemocrático e antipopular. A terceira e última versão da BNCC, foi elaborada pela Gestão Mendonça Filho/Maria Helena Guimarães de Castro, vinculada a concepção neoliberal-flexível extremada, privatista e avessa à participação e representação popular. A terceira versão foi apresentada, após a tramitação obscura da Medida Provisória no 746, de 22 de setembro de 2016 e sua definição na forma da Lei n ${ }^{\circ}$ 13.415, de 16 de fevereiro de 2017 (SILVA, 2017)21. Assim, em abril de 2017, a Gestão Mendonça Filho/Maria Helena Guimarães de Castro, apresentou uma terceira versão fragmentada, separando o Ensino Infantil/Fundamental do Ensino Médio, de forma a apresentar uma concepção de BNCC cindida e fragmentada, desvirtuando a concepção de Educação Básica.

Uma das estratégias autocráticas adotadas pela Gestão Mendonça Filho/Maria Helena Guimarães de Castro, foi recompor o Conselho Nacional de Educação, como forma de controlar a aprovação da contrarreforma do sistema educacional brasileiro. O Conselho Nacional de Educação possui atribuições normativas, deliberativas e de assessoramento ao MEC, estruturado em um sistema bicameral (Câmera de Educação Básica/CEB e Câmara de Educação Superior/CES), constituindo-se o Conselho Pleno, composto por 24 membros, sendo que os Secretários de Educação Básica e Superior do MEC são membros natos. Os conselheiros possuem mandatos de quatro anos, sendo possível reconduzi-los. No dia 11 de maio, um dia antes de ser afastada da presidência, pela histórica votação do Senado brasileiro que marchava para a consumação do Golpe de Estado ${ }^{22}$, Dilma Rousseff havia nomeado 12 membros do Conselho Nacional de Educação. Todavia, Golpes de Estado não costumam respeitar a legalidade e os princípios democráticos, sendo que um dos primeiros atos da Gestão Mendonça Filho/Maria Helena Guimarães de Castro foi o de 
revogar a nomeação ${ }^{23}$. Por outro lado, uma semana antes de se afastar do cargo de Ministro da Educação, na medida em que a legislação eleitoral exigia o afastamento de candidatos ao pleito de 2018, Mendonça Filho antecipou em seis meses a nomeação dos novos conselheiros, reconduzindo Ivan Claudio Pereira Siqueira, da Câmara de Educação Básica, e Joaquim José Soares Neto, Maurício Eliseu Costa Romão e Yugo Okida, da Câmara de Educação Superior, para mais um mandato de quatro anos; ao mesmo tempo, nomeou cinco novos membros para novos mandatos, dentre os quais incluíam-se Maria Helena Guimarães de Castro e Mozart Neves Ramos, para a Câmara de Educação Básica; e, Marco Antônio Marques da Silva, Sergio de Almeida Bruni e Robson Maia Lins, para a Câmara de Educação Superior.

Como forma de atribuir algum nível de legitimidade a um processo autocrático, a Gestão Mendonça Filho/Maria Helena Guimarães de Castro determinou a realização de cinco Audiências Públicas, definidas por região: a) Sul, Florianópolis-SC, 11 de maio de 2018; b) Sudeste, São Paulo-SP, 08 de junho de 2018; c) Nordeste, Fortaleza-CE, 05 de julho de 2018; d) Norte, Belém-PA, 10 de agosto de 2018; e, e) Centro-Oeste, Brasília-DF, 14 de setembro de 2018. As Audiências Públicas foram acompanhadas por protestos em todo país, sendo que a de São Paulo teve que ser cancelada ${ }^{24}$, devido aos protestos que denunciavam os procedimentos autocráticos adotados.

Em agosto de 2017 o Consed e a Undime lançaram o Guia de Implementação ${ }^{25}$ da BNCC, como forma de reorganizar de cima para baixo as secretarias da educação, para a implementação da Base do Golpe. No apagar das luzes de 2017, o Conselho Nacional de Educação aprovou o Parecer CNE/CP n¹5, de 15 de dezembro de 201726, instituindo a Base Nacional Comum Curricular para os Ensinos Infantil e Fundamental, homologada no dia 20 de dezembro de 201727. Um ano após, no dia 04 de dezembro de 2018, o CNE se reuniu e aprovou a BNNC para o Ensino Médio, homologada pelo Governo provisório de exceção de Michel Temer (MDB-PSDB-DEM), no dia 14 de dezembro de 2018. Deve-se destacar que nesse processo, a Gestão Mendonça Filho/Maria Helena Guimarães de Castro aprovou as Novas Diretrizes Curriculares Nacionais para o Ensino $\mathrm{Médio}^{28}$, de tal forma a que instituiu e regulamentou a educação à distância no Ensino Médio, permitindo que 20\% da carga horária pudesse ser feita à distancia, para o período matutino; 30\% para o período noturno; e, até 80\% para a Educação de Jovens e Adultos.

Art. 10. Os currículos do ensino médio são compostos por formação geral básica e itinerário formativo, indissociavelmente. Art. 11. A formação geral básica é composta por competências e habilidades previstas na Base Nacional Comum Curricular (BNCC) e articuladas como um todo indissociável, enriquecidas pelo contexto histórico, econômico, social, ambiental, cultural local, do mundo do trabalho e da prática social, e deverá ser organizada por áreas de conhecimento: I - linguagens e suas tecnologias; II matemática e suas tecnologias; III - ciências da natureza e suas tecnologias; IV - ciências humanas e sociais aplicadas. $\int 1^{\circ} \mathrm{A}$ organização por áreas do conhecimento implica o fortalecimento das relações entre os saberes e a sua contextualização para apreensão e intervenção na realidade, requerendo planejamento e execução conjugados e cooperativos dos seus professores. $\int 2^{\circ} \mathrm{O}$ currículo por área de conhecimento deve ser organizado e planejado dentro das áreas de forma interdisciplinar e transdisciplinar. $\int 3^{\circ}$ A formação geral básica deve ter carga horária total máxima de 1.800 (mil e oitocentas) horas, que garanta os direitos e objetivos de aprendizagem, expressos em competências e habilidades, nos termos da Base Nacional Comum Curricular (BNCC). \ $4^{\circ}$ Devem ser contemplados, sem prejuízo da integração e articulação das diferentes áreas do conhecimento, estudos e práticas de: I - língua portuguesa, assegurada às comunidades indígenas, também, a utilização das respectivas línguas maternas; II - matemática; III - 
conhecimento do mundo físico e natural e da realidade social e política, especialmente do Brasil; IV - arte, especialmente em suas expressões regionais, desenvolvendo as linguagens das artes visuais, da dança, da música e do teatro; V - educação física, com prática facultativa ao estudante nos casos previstos em Lei; VI - história do Brasil e do mundo, levando em conta as contribuições das diferentes culturas e etnias para a formação do povo brasileiro, especialmente das matrizes indígena, africana e europeia; VII - história e cultura afro-brasileira e indígena, em especial nos estudos de arte e de literatura e história brasileiras; VIII - sociologia e filosofia; IX - língua inglesa, podendo ser oferecidas outras línguas estrangeiras, em caráter optativo, preferencialmente o espanhol, de acordo com a disponibilidade da instituição ou rede de ensino. $\int 5^{\circ} \mathrm{Os}$ estudos e práticas destacados nos incisos de I a IX do $\int 4^{\circ}$ devem ser tratados de forma contextualizada e interdisciplinar, podendo ser desenvolvidos por projetos, oficinas, laboratórios, dentre outras estratégias de ensino-aprendizagem que rompam com o trabalho isolado apenas em disciplinas. $\int 6^{\circ}$ Devem ser incluídos temas exigidos por legislação e normas específicas, na forma transversal e integradora, tais como o processo de envelhecimento e o respeito e valorização do idoso; os direitos das crianças e adolescentes; a educação para o trânsito; a educação ambiental; a educação alimentar e nutricional; a educação em direitos humanos; e a educação digital. $\int 7^{\circ}$ A critério dos sistemas de ensino, a formação geral básica pode ser contemplada em todos ou em parte dos anos do curso do ensino médio, com exceção dos estudos de língua portuguesa e da matemática que devem ser incluídos em todos os anos escolares.

Deve-se destacar que a Base do Golpe constitui-se enquanto documento orientador e definidor dos conteúdos que deverão estruturar os processos de elaboração/produção dos livros didáticos, de tal forma que os livros didáticos irão apenas se restringir aos conteúdos contemplados na e pela BNCC, deixando de fora questões importantes, como o debate acerca das questões LGBT, de gênero e étnico-racial, fundamentais para a garantia e efetivação das liberdades civis, políticas e sociais no Brasil do século XXI. Ao mesmo tempo, trata-se de um documento que reafirma e aprofunda a política educacional neoliberalflexível, reduzido e limitado na e pela avaliação de larga escala. A Base do Golpe não apenas orienta, mas determina a política educacional de produção de Livros Didáticos e de Formação de Professores. Portanto, define o tipo e perfil de professores a serem formados para o próximo ciclo, na medida em que os cursos de licenciatura e pedagogia terão que se adequar a estrutura administrativa-organizativa e pedagógica definidos.

\section{Parte III: A Base do Golpe: uma colonização de novo tipo.}

A preocupação com a criação de padrões estaduais de educação surgiu nos EUA, no início dos anos de 1990, em um contexto de ofensiva do capital sobre o trabalho e hegemonização do neoliberalismo flexível extremado. Tratar-se-ia de uma agenda de política educacional surgida no centro e rapidamente disseminada para a periferia capitalista, via organismos multilaterais. A agenda desenhou rapidamente uma nova concepção de educação que passou a impor-se de forma global. Pode-se observar que no início dos anos 2000, todos os Estados ianques já haviam desenvolvido e adotado seus próprios padrões de aprendizado, que especificavam o que os alunos da $3^{a}$ à $8^{a}$ série, bem como do Ensino Médio deveriam ser capazes de aprender a fazer. Tratar-se-ia de adotar e difundir um tipo particular de concepção pedagógica tecnicista, difusora e produtora de uma concepção de ciência pretensamente neutra, técnica, estruturada nos princípios de racionalidade, eficiência e produtividade, a partir dos quais os processos educativos deveriam ser objetivos e operacionais. Proceder-se-ia pela implementação de um tipo particular de padronização, 
mecanização e automação do sistema de ensino, no qual professor e aluno apareceriam enquanto meros executores de um processo, cuja concepção, planejamento, coordenação e controle ficariam a cargo de especialistas supostamente habilitados, neutros, objetivos e imparciais.

No caso dos Estados Unidos da América, cada Estado havia constituído uma concepção de proficiência, tida como adequada e a ser alcançada ao final de cada etapa da Educação Básica. Tratar-se-ia de padronizar as concepções de proficiência, sendo este o objetivo e a função social da implementação dos padrões estaduais do Common Core. Nos EUA, o processo constitutivo do Common Core State Standards ${ }^{29}$ se deu em 2009, a partir do pacto firmado por governadores e comissários estaduais de educação de 48 Estados, dois territórios e o Distrito de Columbia, na ocasião filiaram-se ao National Governors Association Centerfor Best Practices (NGA Center) e o Conselho de Chief School Officers do Estado (CCSSO). Tratar-se-ia de estabelecer padrões estaduais de núcleos comuns, divididos em duas categorias: a) padrões de prontidão para a faculdade e a carreira, que abordariam o que os alunos deveriam saber e entender quando se formassem no Ensino Médio; e, b) padrões K-12, que abordariam as expectativas para o Ensino Fundamental e Médio. Ou seja, os "especialistas" que conduziram o Common Core State Standards recomendavam a criação de núcleo comum de padrões internacionalmente referenciados, em matemática e linguagem, para as classes K-12, como forma de garantir que todos os estudantes dominassem os conhecimentos e habilidades mínimas, como uma forma de alinhar o sistema educacional a competitividade difundida pela ideologia da globalização.

Nos EUA, como os Estados federativos possuem autonomia relativa, frente ao governo central, a partir de 2012, os Estados e territórios passaram por seus próprios processos de avaliação de adoção, revisão e ratificação das normas estaduais do Common Core. Em cada caso, depois de analisar os novos padrões, os conselhos estaduais de educação, governadores, legisladores e/ou diretores escolares do Estado tomaram medidas para substituir seus padrões existentes pelos padrões estaduais do Common Core. Apesar da maioria dos Estados terem adotado o CCSS em ELA/alfabetização e matemática, alguns não adotaram. Hoje, 41 Estados, o Distrito de Colúmbia, quatro territórios e a Atividade Educacional do Departamento de Defesa (DoDEA) adotaram o Common Core e estão implementando os padrões de acordo com seus próprios cronogramas.

A contrarreforma do sistema educacional brasileiro era uma das agendas do Golpe de 2016, de tal forma a utilizar o modelo ianque como parâmetro para a implementação da Lei no 13.415 , de 16 de fevereiro de 2017, via Medida Provisória 746/2016 e aprovação da BNCC. Assim, no Brasil, a discussão acerca da adoção de uma Base Nacional Comum Curricular seguiu as tendências autocráticas do Estado brasileiro, tendo no Movimento pela Base, seu principal sujeito político. O Movimento pela Base define-se da seguinte maneira:

[...] um grupo não governamental de profissionais da educação que desde 2013 atua para facilitar a construção de uma Base de qualidade. O grupo promove debates, produz estudos e pesquisas com gestores, professores e alunos e investiga casos de sucesso em vários países ${ }^{30}$. 
Trata-se de um "Movimento" articulado, gerido e dinamizado na e pela Sociedade Civil do Capital, na medida em que todos os bancos de ideias do capital encontram-se representados, como sua composição demonstra:

Aléssio Costa Lima (Presidente da Undime); Alex Canziani (Deputado Federal e presidente da Frente Parlamentar da Educação); Ana Inoue (Consultora do banco Itaú BBA); André Duarte Stábile (Ex-secretário municipal de Educação de São Caetano do Sul); Angela Dannemann (Superintendente da Fundação Itaú Social); Anna Helena Altenfelder (Presidente do Conselho Administrativo do Cenpec); Anna Penido (Diretora executiva do Instituto Inspirare); Antônio Ibañez Ruiz (Ex-membro do Conselho Nacional de Educação); Antonio Neto (Consultor do Instituto Ayrton Senna); Artur Bruno (Professor de História e Geografia e Secretário do Meio Ambiente do Ceará); Beatriz Cardoso (Diretora executiva do Laboratório de Educação); Beatriz Ferraz (Diretora da Escola de Educadores, Consultora de educação do Itaú BBA e do Banco Mundial); Camila Pereira (Diretora de Políticas Educacionais da Fundação Lemann); Carmen Neves (Consultora do MEC); Claudia Costin (Diretora do CEIPE/FGV); Cleuza Repulho (Ex-presidente da Undime); David Saad (Diretor-presidente do Instituto Natura); Denis Mizne (Diretor da Fundação Lemann); Dorinha Seabra Rezende (Deputada federal e integrante da Comissão de Educação da Câmara); Eduardo de Campos Queiroz (Diretor Presidente da Fundação Maria Cecilia Souto Vidigal); Egon Rangel (Professor do departamento de linguística da PUC-SP); Fernando Almeida (Diretor Nacional de Educação e Cultura do SESC); Francisco Aparecido Cordão (Ex-membro do CNE e titular da Academia Paulista de Educação); Frederico Amancio (Ex-Presidente do Consed e Secretário Estadual de Educação de Pernambuco); Guiomar Namo de Mello (Consultora de projetos educacionais e de formação de professores na SEE- SP e no MEC e membro do Conselho Estadual de Educação de SP); Joane Vilela (ExSecretária de Educação de Foz do Iguaçu, ex- Secretária Adjunta de Educação de SP e ex-Dir. de Orientação Técnica de SP); João Roberto da Costa de Souza (Exsecretário de Educação de Jacareí; José Fernandes de Lima (Ex-membro do Conselho Nacional de Educação); Kátia Stocco Smole (Secretária de Educação Básica do MEClicenciada); Lúcia Couto (Ex-Secretária de Educação de Embu das Artes/SP); Luís Carlos de Menezes (Professor Sênior do Instituto de Física da USP. Membro do CEE de São Paulo e do Conselho Técnico Científico da Capes/MEC para Educação Básica. Integrou o grupo de especialistas do MEC para a elaboração da versão preliminar da Base); Magda Soares (Professora Titular Emérita da Faculdade de Educação da Universidade Federal de Minas Gerais); Maria do Pilar Lacerda (Diretora da Fundação SM); Maria Helena Guimarães de Castro (Ex-Secretária-executiva do MEC); Maria Inês Fini (Presidente do INEP-licenciada); Mariza Abreu (Consultora em educação da CNM); Miguel Thompson (Presidente do Instituto Singularidades); Mozart Neves Ramos (Diretor de articulação e Inovação do Instituto Ayrton Senna); Naércio Aquino Menezes Filho (Coordenador do Centro de Políticas Públicas do Insper); Natacha Costa (Diretora da Cidade Escola Aprendiz); Osvaldo Tietê da Silva (Presidente da Rede Integrada de Escolas Públicas do Rio Grande do Sul, associação de diretores de escolas públicas que busca uma educação pública de qualidade); Patrícia Mota Guedes (Gerente de Educação da Fundação Itaú Social); Paula Louzano (Pesquisadora visitante da Universidade Stanford); Paulo Schmidt (Secretaria de Educação do Estado do Paraná); Pedro Villares (Presidente do Conselho do Instituto Natura); Priscila Cruz (Presidente executiva do Todos Pela Educação); Raimundo Feitosa (Secretário Municipal de Educação de São Luis-MA); Raph Gomes (Diretor de Currículos e Educação Integral do MEC-licenciado); Raul Henry (Vice-governador de Pernambuco); Ricardo Chaves de Rezende Martins (Consultor Legislativo da Câmara dos Deputados na área de Educação); Ricardo Henriques (Superintendente do Instituto Unibanco); Ricardo Paes de Barros (Economista-chefe do Instituto Ayrton Senna e professor da Cátedra Instituto Ayrton Senna do Insper); Rodrigo Hübner Mendes (Superintendente do Instituto Rodrigo Mendes); Rossieli Soares da Silva (Ministro da Educação-licenciado); Ruben Klein (Consultor da Fundação Cesgranrio); Simone André (Gerente executiva da área de Educação do Instituto Ayrton Senna); Suely Menezes (Presidente do Fórum Nacional dos Conselhos Estaduais de Educação e conselheira do CNE);Teresa Pontual (Gerente executiva do 
CEIPE/FGV); Tereza Perez (Diretora da Comunidade Educativa Cedac); Thiago Peixoto (Deputado Federal - PSD/GO); e, Vera Cabral (Diretora Executiva da Abrelivros). ${ }^{31}$

O "Movimento" adota uma concepção privatista e mercadológica da educação, para todas as etapas da Educação Básica e Superior. Optou-se por adotar as aspas, justamente, porque não se trataria propriamente de um movimento social (ao menos, do ponto de vista conceitual), aproximando-se muito mais de uma concepção de aparelho privado de hegemonia, capaz de produzir e difundir um conjunto de ideias, como forma de construir o consenso acerca de determinado projeto político. A mesma definição pode ser atribuída ao Instituto Ayrton Senna (financiado por grandes corporações empresarias, com destaque em seu site para o Itaú $\left.{ }^{32}\right)$.

Apesar de ter tido grande influência nos Governos Dilma Rousseff (2011-2016), tanto o Movimento pela Base, quanto o Instituto Ayrton Senna, passaram a influenciar direta e unilateralmente na definição de política educacional brasileira, com a deflagração do Golpe de Estado de 2016, sendo responsável pela adoção da política educacional do Governo provisório de Exceção de Michel Temer (MDB-DEM-PSDB), no caso da educação, conduzida pela Gestão Mendonça Filho/Maria Helena Guimarães de Castro; bem como, flertou com o governo eleito, no âmbito do Estado de Exceção, a partir de eleições parcialmente interditadas, Jair Bolsonaro (PSL), indicando Mozart Neves Ramos, para o MEC. Todavia, o nome fora vetado pela Bancada Evangélica ${ }^{33}$, grupos olavistas e militares, que indicaram para a pasta o obscurantista Ricardo Vélez ${ }^{34}$.

Do ponto de vista formal, pode-se dizer que a Base Nacional Comum Curricular (BNCC) caracteriza-se por ser um Documento normativo que determina os conhecimentos essenciais da Educação Básica, desde o Ensino Infantil ao Ensino Médio, dessa forma o Currículo da Educação Básica, tanto de Escolas Públicas quanto Privadas, seria constituído e desenhado a partir das regulamentações e garantias normatizadas pela BNCC. Nesse sentido, o processo constitutivo da BNCC acaba por transformá-la em um Curriculo Instrumental Oculto, a partir do qual, por um lado, determina o conteúdo a ser desenvolvido nos sistemas educacionais, de outro, constituiu-se um Currículo Vazio, como forma de estimular o mercado da educação e submeter o sistema educacional as necessidades do mercado.

A BNCC começou a ser discutida, tanto no âmbito da Sociedade Civil dos Mundos do Capital quanto do Trabalho, no ano de 2015; e, foi aprovada pelo Conselho Nacional de Educação, em 04 de dezembro de 2018. Portanto, os primeiros processos de discussão acerca da BNCC encontram-se marcados pela política de conciliação de classes dos governos petistas (2003-2016), tendo como característica o pacto social entre capital e trabalho. Todavia, desde as Manifestações de 2013, a política de conciliação de classes dos governos petistas demonstrava sinais de esgotamento e colapso. A crise do capital do biênio 2008-9 alcançou o Brasil de forma drástica a partir de 2012, de tal forma a afetar drasticamente a sociedade brasileira. Rapidamente, a crise econômica consubstanciou uma crise política aguda, ambas suprassumidas em uma crise social que levou ao colapso à Nova República (1988-2016).

O processo de discussão e deliberação acerca da BNCC não passou incólume pela crise brasileira, na medida em que a crise social possibilitou a efetivação de um Golpe de Estado, consumado no dia 31 de 
agosto de $2016^{35}$, com o propósito de redesenhar pelo alto as instituições políticas brasileiras, de tal forma a proteger o grande capital dos efeitos da crise, como forma de garantir e preservar os negócios do capital financeiro-rentista. Tratava-se de uma crise de hegemonia que pela via do Golpe de Estado alteraria o bloco no poder no Brasil. Com o Golpe de Estado a correlação de forças se alterou drasticamente, em favor da Sociedade Civil do Capital, de tal forma a sufocar toda e qualquer pauta emancipatória da Sociedade Civil do Mundo do Trabalho, bem como bloquear qualquer alternativa e/ou possibilidade de participação e representação autônoma da classe trabalhadora nas instituições políticas brasileiras.

No âmbito do sistema educacional brasileiro, a Sociedade Civil do Mundo do Capital conduziu um rápido processo contrarreformista, iniciado via anulação das nomeações do Conselho Nacional de Educação, feitas por Dilma Rousseff; recomposição forçada do CNE; e, emissão de Medida Provisória. A Medida Provisória contrarreformava o sistema educacional brasileiro, na medida em previa que 60\% dos conteúdos seriam definidos pela BNCC e os demais 40\% constituiriam um vazio curricular a ser preenchido de acordo com os interesses do mercado, visto que os espaços de discussão e deliberação encontravam-se bloqueados pelo Golpe. A Contrarreforma do sistema educacional brasileiro, no âmbito do Ensino Médio instituiu a obrigatoriedade do ensino em tempo integral, obrigando as Escolas Públicas e Privadas, a ampliarem suas respectivas carga-horárias anuais de 800 para 1000, até o ano de 2022. Além de tais medidas, a Contrarreforma estabeleceu que a BNCC deveria restringir-se a 1800 horas, de tal forma a deixar as demais 1200 horas a critério dos arranjos locais e regionais, um eufemismo para caracterizar o V azio Currículo Instrumental, forjado pelo e para o mercado. Trata-se de um artificio autocrático que cria um vazio curricular de 1.200 horas, a ser ocupado e instrumentalizado pela iniciativa privada, como forma de colonizar e instrumentalizar o Currículo, visto que os espaços de discussão e deliberação democráticos foram interditados pelo Golpe de Estado de 2016. Ora, o vazio curricular, de forma direta e intencional, retira um conjunto de conteúdos e estrutura um Curriculo Instrumental Oculto, aparentemente constituído de forma democrática e articulado as necessidades dos arranjos produtivos e socioculturais e político-econômicos regionais e locais. Enquanto processo de objetivação e exteriorização da Lei no 13.415, de 16 de fevereiro de 2017, a BNCC institui um Currículo Instrumental Oculto, flexível, para atender a lógica fragmentária e excludente presente nos itinerários formativos: a) linguagens e suas tecnologias; b) matemática e suas tecnologias; c) ciências humanas e sociais aplicadas; d) ciências da natureza; e, e) ensino técnico profissionalizante, estruturado no notório saber.

Assim, a Base do Golpe elegeu dez competências (1. conhecimento; 2. pensamento científico critico e criativo; 3. repertorio cultural; 4. comunicação; 5. cultura digital; 6. trabalho e projeto de vida; 7. argumentação; 8. autoconhecimento e autocuidado; 9.empatia e cooperação; 10. responsabilidade e cidadania) que se desdobram em quatro grandes áreas, a partir das quais se definiriam as disciplinas e seus respectivos conteúdos: a) Matemática; b) Ciências da Natureza; c) Linguagens; e, d) Ciências Humanas. Trata-se de um processo de dissolução do conteúdo/disciplinas em competências gerais, como forma de viabilizar um tipo de Currículo Instrumental Oculto enxuto e flexível, adaptando as diferentes dinâmicas dos mercados locais e regionais.

O Curriculo Instrumental Oculto esvazia os Componentes Curriculares, criando a obrigatoriedade em todos os anos do Ensino Médio de somente dois componentes a serem instrumentalizados: a) Matemática; 
e, b) Língua Portuguesa; sendo que, sob o discurso ideológico da interdisciplinaridade, os demais Componentes Curriculares passam a ser diluídos e flexibilizados em áreas do conhecimento. Todavia, por uma questão lógica, deve-se destacar que não existe interdisciplinaridade sem disciplinas que a consubstancie. Trata-se de um artificio retórico, para limitar, restringir e, no limite, extinguir um conjunto de Componentes Curriculares, importantes para a formação de indivíduos autônomos, auto-reflexivos e emancipados.

De acordo com a própria Contrarreforma, o chamado Novo Ensino Médio seria implementado após a aprovação da BNCC. Claramente, a Contrarreforma criou um Vaz̧io Curricular Instrumental, por um lado, e um Currículo Oculto Instrumental, por outro, eliminando disciplinas e conteúdos importantes: o primeiro, visa viabilizar empreendimentos privados no âmbito da Educação Básica, voltada principalmente para o mercado de Educação à Distância (EaD), ao mesmo tempo em que se submete a dinâmica e movimento imediatista do mercado local e regional, submetendo e restringindo o sistema educacional e o processo formativo ao tecnicismo; o segundo, homogeneíza o sistema educacional nacional, de tal forma a eliminar a cultura e um conjunto de saberes locais e regionais. Deve-se destacar que de acordo com a Pesquisa Nacional por Amostra de Domicílio Contínuo (PNAD/2016), 56,5 milhões de estudantes frequentaram o sistema educacional brasileiro, naquele ano, sendo que, 73,5\% acessaram a Rede Pública, e, 26,5\% a Rede Privada ${ }^{36}$. Os dados demonstram que, a Rede Pública é responsável por quase $80 \%$ das matriculas dos alunos em idade escolar, na Educação Básica. Trata-se de um imenso mercado educacional, em potencial, a ser explorado. Todavia, contraditoriamente, um mercado potencial, financiado e garantido pelo Estado.

A Contrarreforma do sistema educacional brasileiro, procurou difundir uma concepção de Novo e ampliado Ensino Médio, como forma de positivá-lo e constituir um "consenso artificial-forçado" acerca de sua implementação. Enquanto o projeto, via Medida Provisória, tramitava no Parlamento; e, os estudantes o questionavam, via Movimento de Ocupação de Escolas ${ }^{37}$, por todo país; o Governo provisório de exceção de Michel Temer (MDB-DEM-PSDB), difundia, via corporações monopolistas-golpistas dos meios de comunicação, um pesado arsenal propagandístico acerca do chamado Novo Ensino Médio, apresentandoo a população como aprovado e em processo de implementação ${ }^{38}$.

A Base do Golpe encontra-se estruturada na Lei no 13.415, de 16 de fevereiro de 2017, na medida em que representa a determinação plena da política educacional do Golpe de Estado soft de 2016, a partir do qual se impõe, pela via da formação da subjetividade, a submissão e a precarização irrestrita e incondicional da classe trabalhadora, de tal forma a constituir um tipo de consenso conservador, forjado a partir da naturalização das misérias materiais e espirituais produzidas pelo neoliberalismo-flexível extremado, como forma de difundir e enraizar um tipo particular de fascistização do cotidiano, a partir do qual a barbárie assume a forma reificada de civilização. A Base do Golpe reestrutura a concepção de formação da subjetividade dos jovens, em uma perspectiva reificada, aparentemente, destituída de sentido e significado.

A Lei $n^{\circ}$ 13.415, de 16 de fevereiro de 2017, alterou de cima para baixo a concepção de processo formativo e, consequentemente, a concepção de administração e organização dos sistemas educacionais; a concepção de avaliação; o Currículo; e, a concepção de formação de professores da Educação Básica. Assim, ao contrário do que os apologetas da Reforma do Ensino Médio defendiam: 1. Não se trata de uma Reforma, 
mais de uma Contrarreforma, na medida em que restringe e limita o direito à educação de parte significativa da sociedade brasileira, particularmente dos filhos da classe trabalhadora. Trata-se da reversão sistemática dos processos de universalização da Educação Básica e Superior no Brasil, em todas as suas etapas; 2. Não se trata de uma Contrarreforma focalizada, instituída no âmbito do Ensino Médio, mas de uma Contrarreforma, indireta e estrutural, de todo o sistema educacional brasileiro, desde o Ensino Infantil ao Superior; 3. A Contrarreforma altera a concepção de formação, tanto dos alunos, quanto dos professores, esvaziando-a e submetendo-a ao pragmatismo e utilitarismo do cotidiano, submetendo-a aos parâmetros do novo ciclo de acumulação do capital no Brasil, fundamentado na precarização do trabalho, na extrema espoliação, na baixa escolarização e em diminutos salários; 4. A Contrarreforma aprofunda os níveis de desigualdade, na medida em que interdita o jovem trabalhador advindo das classes trabalhadoras, no novo, flexível, fragmentado, precarizado e esvaziado Ensino Médio. Assim, os cinco itinerários formativos, por um lado, assume ideologicamente a forma de diversidade, autonomia e inclusão; e, por outro, assume a materialidade mundana da colonização pela subjetividade, homogeneização, reificação e exclusão. Trata-se da alegoria machadiana descrita na relação entre o Brasil oficial e real; 5. Altera a concepção de formação de professores, na medida em que o Currículo dos Cursos de Licenciatura e Pedagogia precisam se adequar aos novos parâmetros de formação da Educação Básica.

\section{Considerações finais.}

O Golpe de Estado soft de 2016 abriu um cenário de Estado de Exceção no Brasil que vem se aprofundando progressivamente, em uma perspectiva de fechamento do regime. Assim, o Golpe de Estado dividiu-se, até o momento, em três etapas: 1 . Derrubada da presidente eleita, como uma resposta à crise de hegemonia que necessitava de uma recomposição do bloco no poder e, consequentemente, de uma reestruturação do sistema político brasileiro que implicava na fragilização e, no limite, na destruição dos principais partidos que forjaram a Nova República: PT-PSDB-MDB; 2. O encarceramento do principal líder sindical latino-americano dos últimos 40 anos, como forma de garantir e efetivar a agenda do capitalimperialismo no Brasil, bloqueando qualquer possibilidade de reversão da agenda do Golpe, visto que em todos os cenários de pesquisa de intenção de votos, derrotaria qualquer um dos candidatos do partido da ordem (SILVA, 2016) 39; 3. A realização de eleições parcialmente interditadas. As eleições de 2018 não podem ser caracterizadas enquanto eleições livres, visto que o principal candidato à presidência da república teve seus direitos civis e políticos cassados ilegalmente, sem o devido processo legal, como prevê a Constituição de 1988. Assim, a eleição de Jair Bolsonaro (PSL) é parte constitutiva e integrante do Golpe de Estado, tornando-se possível somente em um cenário atípico e anomico, no e a partir do qual as instituições políticas brasileiras, via Poder Judiciário e órgãos de controle de Estado, interditaram não somente a candidatura do principal candidato à presidência da república, mas de um conjunto de outros políticos do PT-PSDB-MDB, mediante ações policiais hollywoodianas, com conduções coercitivas e prisões temporárias questionáveis, no decorrer do processo eleitoral; além do uso do indiscriminado do firehosing, como estratégia de disseminação de mentiras em massa, via redes sociais, usada como propaganda política 
de Bolsonaro, constituindo-se uma maquina de campanha subterrânea. Somado a estratégia de firehosing, que impediu a vitória de políticos progressistas em todo país, tanto para a Câmara dos Deputados e Senado, quanto para os governos estaduais; a ação político-policialesca da Operação Lava Jato redesenhou a composição político-eleitoral no Brasil, tanto nos governos estaduais, quanto no Congresso Nacional.

A contrarreforma do sistema educacional brasileiro encontra-se diretamente articulada as fases do Golpe de Estado: $1^{a}$ etapa: aprovação, via Medida Provisória, da chamada Reforma do Ensino Médio; $2^{\mathrm{a}}$ etapa: redefinição do Conselho Nacional de educação, como forma de alterar pelo alto os documentos de ordenação jurídico-política do sistema educacional brasileiro. $\mathrm{Na}$ segunda etapa, interrompeu-se os processos de discussão/deliberação de democracia participativa, a partir dos quais se vinha encaminhando a construção da BNCC. Tratou-se de um processo autocrático, antidemocrático e antipopular, de centralização e concentração do poder na Gestão Mendonça Filho/Maria Helena Guimarães de Castro, alterando-se os métodos e os procedimentos de construção da BNCC. O governo em questão tratou de cindi-la: a) aprovação da BNCC do Ensino Infantil/Fundamental; e, b) aprovação do Ensino Médio. Nesse interim, a Gestão Mendonça Filho/Maria Helena Guimarães de Castro aprovou as Novas Diretrizes Curriculares Nacionais para o Ensino Médio. $3^{a}$ etapa: implementação da Base do Golpe. Esta será a incumbência do governo de exceção de Jair Bolsonaro (PSL), pelo qual, até o momento, já passaram dois Ministros da Educação: a) o obscurantista/olavista Ricardo Vélez Rodrigues ${ }^{40}$, demitido, pela mais absoluta incompetência; e, b) Abraham Weintraub ${ }^{41}$ : homem do mercado financeiro, sem nenhum tipo de formação e/ou experiência na área educacional.

\section{Referências}

ADORNO, T. (1998). Critical models: Interventions and Catchwords. New York: Columbia University Press.

ADORNO, Theodor. Educação e Emancipação. Trad. WolfgangLeo Maar. - Rio de Janeiro: Paz e Terra, 1995.

APPLE, M. (1979). Ideology and Curriculum. New York: Routledge.

APPLE, M. (1993). Official Knowledge: Democratic Education in a Conservative Age. New York: Routledge.

APPLE, M. (1996). Cultural Politics and Education. New York: Routledge.

APPLE, M. (2001) (1ª ed. 1985, Education and Power, Boston: Routledge). Educação e poder. Porto: Porto Editora

APPLE, M., \& BEANE, J. A. (1995). Democratic Schools. New York: Routledge.

BARRETO, E. B. S. Fato: IV Conferencia Brasileira de Educação. Revista ANDE, ano 6, n. 12. 1987.

CAFARDO, Renata. Bancada Evangélica reage a nome de Mozart Neves para o Ministério da Educação.

Publicado em 21 nov. 2018. Disponível em https://educacao.estadao.com.br/blogs/blog-renatacafardo/mozart-neves-sera-o-ministro-de-educacao-de-bolsonaro/ Acesso em 13 mar. 2019.

CÂMERA DOS DEPUTADOS. Lei n ${ }^{\circ}$ 4.024, de 20 de dezembro de 1961. Disponível em https://www2.camara.leg.br/legin/fed/lei/1960-1969/lei-4024-20-dezembro-1961-353722publicacaooriginal-1-pl.html Acesso em 07 mar.2019. 
CAMPOS, Ana Cristina. Ensino Básico tem 73,5\% dos alunos em escolas públicas, diz IBGE. In. Agência Brasil. Publicado em 21 dez. 2017. Disponível em:

http://agenciabrasil.ebc.com.br/educacao/noticia/2017-12/ensino-basico-tem-735-dos-alunos-emescolas-publicas-diz-ibge Acesso em 18 fev.2019.

CARTA DE GOIÂNIA. IV Conferência Brasileira de Educação, realizada de 02 a 05 de setembro de 1986. Disponível em:

http://www.floboneto.pro.br/ pdf/outrosdoc/cartadegoi\%C3\%A2nia1986 4cbe.pdf Acesso em 06 mar. 2019.

COMMON CORE STATE STANDARDS http://www.corestandards.org/ Acesso em 13 mar. 2019.

G1. Bolsonaro demite Vélez e nomeia Abraham Weintraub como ministro da educação. Publicado em 08 abr. 2019. Disponível em https:/g1.globo.com/politica/noticia/2019/04/08/planalto-anuncia-demissaode-ricardo-velez-rodriguez-do-ministerio-da-educacao.ghtml Acesso em 21 abr. 2019.

G1. Processo de impeachment é aberto e Dilma é afastada por até 180 dias. Publicado em 12 mai. 2016. Disponível em http://g1.globo.com/politica/processo-de-impeachment-de-

dilma/noticia/2016/05/processo-de-impeachment-e-aberto-e-dilma-e-afastada-por-ate-180-dias.html Acesso em 05 abr. 2019.

GARCIA, Gustavo; CALGARO, Fernanda; MATOSO, Filipe; LIS, Laís; e, RODRIGUES, Mateus. Senado aprova impeachment, Dilma perde o mandato e Temer assume. In. G1. Publicado em 31 ago.2016. Disponível em http://g1.globo.com/politica/processo-de-impeachment-dedilma/noticia/2016/08/senado-aprova-impeachment-dilma-perde-mandato-e-temer-assume.html Acesso em 22 fev.1019.

GUIA DE IMPLEMENTAÇÃO BNCC. Disponível em https://implementacaobncc.com.br/ Acesso em 05 abr. 2019.

INSTITUTO AYRTON SENNA. Disponível em https://institutoayrtonsenna.org.br/pt-br.html Acesso em 08 abr. 2019.

LUKACS, György. Para uma ontologia do ser social. Trad. Carlos Nelson Coutinho; Lya Luft; Mario Duayer; Nélio Schneider; Rodnei Antônio do Nascimento. São Paulo: Boitempo, 2012.

MANACORDA, Mario Alighiero. Marx e a Pedagogia Moderna. Trad. Newton Ramos de Oliveira. $2^{a}$ ed.- Campinas-SP: Alínea, 2010.

. O princípio educativo em Gramsci: americanismo e conformismo. $-2^{\mathrm{a}} \mathrm{ed}$. -. Trad. Willian Laços. - Campinas-SP: Alínea, 2013.

MARX, Karl. Manuscritos econômicos filosóficos. Trad. Jesus Ranieri. - São Paulo: Boitempo, 2004.

MATOSO, Filipe; GARCIA, Gustavo. Bolsonaro anuncia Ricardo Vélez Rodríguez como ministro da educação. Publicado em 22 nov. 2018. Disponível em

https://g1.globo.com/politica/noticia/2018/11/22/bolsonaro-anuncia-ricardo-velez-rodriguez-comoministro-da-educacao.ghtml Acesso em 13 mar. 2019.

MINISTÉRIO DA EDUCAÇÃO. Base Nacional Comum Curricular. Publicada em 19 dez.2018.

Disponível em http://basenacionalcomum.mec.gov.br/wpcontent/uploads/2018/12/BNCC 19dez2018 site.pdf Acesso em 04 mar.2019.

MINISTÉRIO DA EDUCAÇÃO. Base Nacional Comum Curricular: Ensino Infantil e Fundamental. Disponível em:

http://portal.mec.gov.br/index.php?option $=$ com docman\&view $=$ download\&alias $=79611$-anexo-textobncc-aprovado-em-15-12-17-pdf\&category slug=dezembro-2017-pdf\&Itemid=30192 Acesso em 05 abr. 2019.

MINISTÉRIO DA EDUCAÇÃO. Diretrizes Curriculares Nacionais (PCNs). Resolução no 03, de 21 de novembro de 2018. Disponível em

http://novoensinomedio.mec.gov.br/resources/downloads/pdf/dcnem.pdf Acesso em 07 abr. 2019. 
MINISTÉRIO DA EDUCAÇÃO. Disponível em: http://historiadabncc.mec.gov.br/documentos/BNCC-APRESENTACAO.pdf Acesso em 05 abr. 2019. MINISTÉRIO DA EDUCAÇÃO. Disponível em: http://historiadabncc.mec.gov.br/documentos/bncc2versao.revista.pdf Acesso em 05 abr. 2019.

MINISTÉRIO DA EDUCAÇÃO. Novo ensino médio 01 e 02. Publicado em 06 jun. 2017. Disponível em https://youtu.be/iIszj0WWqfA e https://youtu.be/4pb1nasqUtQ Acesso em 08 abr. 2019.

MINISTÉRIO DA EDUCAÇÃO. Parecer CNE/CP n¹5, de 15 de dezembro de 2017. Disponível em http://portal.mec.gov.br/index.php?option $=$ com docman\&view $=$ download\&alias $=78631-$ pcp015-17pdf\&category slug=dezembro-2017-pdf\&Itemid=30192 Acesso em 05 abr. 2019.

MINISTÉRIO DA EDUCAÇÃO. Portaria nº 790, de 27 de julho de 2016. Disponível em http://portal.mec.gov.br/index.php?option $=$ com docman\&view $=$ download\&alias $=46471$-link-port- 790 base-curricular-pdf\&category_slug=julho-2016-pdf\&Itemid=30192 Acesso em 05 abr. 2019.

MINISTÉRIO DA EDUCAÇÃO. Resolução CNE/CEB no 4, de 13 de julho de 2010. Disponível em: http://www.crmariocovas.sp.gov.br/Downloads/ccs/concurso 2013/PDFs/resol federal 04 14.pdf Acesso em 05 abr.2019.

MORENO, Ana Carolina. Após protesto, audiência pública sobre a Base Nacional Comum Curricular do ensino médio é cancelada em São Paulo. In. G1. Publicada em 09 jun. 2018. Disponível em https:/g1.globo.com/educacao/noticia/apos-protesto-audiencia-publica-sobre-a-base-nacionalcurricular-do-ensino-medio-e-cancelada-em-sao-paulo.ghtml Acesso em 05 abr. 2019.

MORENO, Ana Carolina; MARQUES, Marília. Após revogar indicações feitas por Dilma, Temer nomeia membros do Conselho Nacional de Educação com seis meses de antecedência. In. G1. Publicado em 04 abr. 2018. Disponível em https://g1.globo.com/educacao/noticia/apos-revogar-indicacoes-feitas-pordilma-temer-nomeia-membros-do-conselho-nacional-de-educacao-com-seis-meses-de-antecedencia.ghtml Acesso em 05 abr. 2019.

MOVIMENTO PELA BASE NACIONAL COMUM. Disponível em http://movimentopelabase.org.br/quem-somos/Acesso em 13 mar. 2019.

MOVIMENTO PELA BASE NACIONAL COMUM. Disponível em http://movimentopelabase.org.br/quem-somos/ Acesso em 13 mar. 2019.

OLIVEIRA, Elida. Abraham Weintraub: saiba quem é o novo ministro da educação. Publicada em 08 abr. 2019. Disponível em https://g1.globo.com/educacao/noticia/2019/04/08/abraham-weintraub-saibaquem-e-o-novo-ministro-da-educacao.ghtml Acesso em 21 abr. 2019.

PRESIDÊNCIA DA REPÚBLICA. Constituição da República Federativa do Brasil de 1988. Disponível em: http://www.planalto.gov.br/ccivil 03/Constituicao/Constituicao.htm Acesso em 06 mar.2019.

PRESIDÊNCIA DA REPÚBLICA. Lei no 13.005, de 25 de junho de 2014 Disponível em: http://www.planalto.gov.br/CCIVIL_03/_Ato2011-2014/2014/Lei/L13005.htm Acesso em 05 abr. 2019.

PRESIDÊNCIA DA REPÚBLICA. Lei no 13.415, de 16 de fevereiro de 2017. Disponível em http://www.planalto.gov.br/ccivil_03/_Ato2015-2018/2017/Lei/L13415.htm Acesso em 21 abr. 2019.

PRESIDÊNCIA DA REPÚBLICA. Lei no 9.394, de 20 de dezembro de 1996. Disponível em http://www.planalto.gov.br/ccivil 03/leis/19394.htm Acesso em 21 abr. 2019.

PRESIDÊNCIA DA REPÚBLICA. Lei no 9.394, de 20 de dezembro de 1996. Disponível em: http://www.planalto.gov.br/ccivil 03/Leis/L9394.htm Acesso em 06 mar. 2019.

PRESIDÊNCIA DA REPÚBLICA. Medida Provisória, nº746, de 22 de setembro de 2016. Disponível em http://www.planalto.gov.br/ccivil_03/Ato2015-2018/2016/Mpv/mpv746.htm Acesso em 21 abr. 2019.

SHIROMA, Eneida Oto. Politica Educacional. - 4ª ed. - Rio de Janeiro: Lamparina, 2011. 
SILVA, Marcelo Lira. A linguagem do consenso nos marcos da regressão cultural. Publicada em 07 ago. 2014. Disponível em https://www.marilia.unesp.br/Home/PosGraduacao/CienciasSociais/Dissertacoes/silva_ml_do_mar.pdf Acesso em 21 abr. 2019.

SILVA, Marcelo Lira. Coup d'État e exclusivismo político-educacional: uma análise da Medida Provisória 746/2016. In. Germinal: Marxismo e Educação em Debate, Salvador, v. 9, n. 3, p. 182-210, dez. 2017.

Disponível em https://portalseer.ufba.br/index.php/revistagerminal/article/view/23726/15289 Acesso em 21 abr. 2019.

SILVA, Marcelo Lira. Ensaio sobre a função social dos partidos na contemporaneidade e o papel dos intelectuais. In. ORG \& DEMO, Marília, v. 18, n. 1, p. 129-140, Jan./Jun., 2017. Disponível em file:///C:/Users/Marcelo\%20Lira/Downloads/7447-Texto \%20do\%20artigo-23918-1-1020171108\%20(2).pdf Acesso em 21 abr. 2019.

SILVA, Marcelo Lira. Notas gramscianas: Golpe de Estado e luta de classes no Brasil do século XXI. In. Movimentação, Dourados, v.04, nº7, p.01-32, 2017. Disponível em http://ojs.ufgd.edu.br/index.php/movimentacao/article/view/8427/4482 Acesso em 21 abr. 2019.

SILVA, Marcelo Lira. Notas gramscianas: Golpe de Estado e luta de classes no Brasil do século XXI. In. Revista MovimentAção. UFGD, v. 4, nº. 7, p. 01-32, 2017. Disponível em: file://C:/Users/Marcelo\%20Lira/Downloads/8427-25513-1-PB\%20(1).pdf Acesso em 07 mar.2019.

SUPREMO TRIBUNAL FEDERAL. Ação Direta de Inconstitucionalidade 4439. Publicada em 27 set. 2017. Disponível em http://www.stf.jus.br/portal/cms/verNoticiaDetalhe.asp?idConteudo=357099 Acesso em 08 abr. 2019.

TOKARNIA, Mariana. Mais de mil escolas no país estão ocupadas em protesto; entenda o movimento. In. Agencia Brasil. Publicado em 25 out. 2016. Disponível em:

http://agenciabrasil.ebc.com.br/educacao/noticia/2016-10/mais-de-mil-escolas-do-pais-estao-ocupadasem-protesto-entenda-o-movimento Acesso em 13 fev. 2019.

\section{Notas:}

${ }^{1}$ Formado em Ciências Sociais e Filosofia, pela Universidade Estadual Paulista - "Júlio de Mesquita Filho" (UNESP/Campus Marília), em nível de Bacharelado e Licenciatura, em ambos os cursos. Mestre em Sociologia (UNESP/Campus Araraquara). Doutor em Ciências Sociais (UNESP/Campus Marília). Pós-Doutorado em História (UFG/Faculdade de História). Professor Substituto nos Cursos de Ciências Sociais e Relações Internacionais (UNESP/Campus Marília), de 2010 a 2013. Professor Efetivo de Sociologia do Instituto Federal de Educação, Ciência e Tecnologia de Goiás/Campus Goiânia, no qual desenvolve atividades de ensino-pesquisa-extensão, em diversos níveis e modalidades, desde abril de 2014. Líder do Núcleo de Estudos e Pesquisas Avançadas - Ética e Política Emancipatória (NEPA-EPE). Professor-pesquisador da Especialização em Políticas e Gestão da Educação Profissional e Tecnológica/Campus Goiânia, na qual leciona, desenvolve pesquisa e orienta. Atua principalmente nas seguintes temáticas: Capitalismo Tardio, Dependente e Associado; Estado Nacional e Capitalismo Periférico; Formação Social Brasileira; Instituições Políticas Brasileiras; Políticas e Gestão da Educação Profissional e Tecnológica; Sociedade Civil do Mundo do Trabalho; Teoria Política do Socialismo; e, Teoria da Democracia. ORCID: Email: marcelo.lira@,unesp.br

2 PRESIDÊNCIA DA REPÚBLICA. Medida Provisória, nº746, de 22 de setembro de 2016. Disponível em http://www.planalto.gov.br/ccivil 03/ Ato2015-2018/2016/Mpv/mpv746.htm Acesso em 21 abr. 2019.

3 PRESIDÊNCIA DA REPÚBLICA. Lei no 13.415, de 16 de fevereiro de 2017. Disponível em http://www.planalto.gov.br/ccivil 03/ Ato2015-2018/2017/Lei/L13415.htm Acesso em 21 abr. 2019.

4 MINISTÉRIO DA EDUCAÇÃO. Base Nacional Comum Curricular. Publicada em 19 dez.2018. Disponível em http://basenacionalcomum.mec.gov.br/wp-content/uploads/2018/12/BNCC 19dez2018 site.pdf Acesso em 04 mar.2019.

5 SILVA, Marcelo Lira. A linguagem do consenso nos marcos da regressão cultural. Publicada em 07 ago. 2014. Disponível em https://www.marilia.unesp.br/Home/Pos-Graduacao/CienciasSociais/Dissertacoes/silva ml do mar.pdf Acesso em 21 abr. 2019.

${ }^{6}$ SILVA, Marcelo Lira. Notas gramscianas: Golpe de Estado e luta de classes no Brasil do século XXI. In. Movimentação, Dourados, v.04, nº7, p.01-32, 2017. Disponível em http://ojs.ufgd.edu.br/index.php/movimentacao/article/view/8427/4482 Acesso em 21 abr. 2019.

${ }^{7}$ SILVA, Marcelo Lira. Notas gramscianas: Golpe de Estado e luta de classes no Brasil do século XXI. In. Revista MovimentAção. UFGD, v. 4, nº. 7, p. 01-32, 2017. Disponível em: file://C:/Users/Marcelo\%20Lira/Downloads/842725513-1-PB\%20(1).pdf Acesso em 07 mar.2019.

8 Associação Nacional de Docentes do Ensino Superior (ANDES), Associação Nacional de Pesquisa e Pós- graduação em Educação (ANPEd), Associação Nacional de Educação (ANDE), Associação Nacional de Profissionais de Administração da 
Educação (ANPAE), Sociedade Brasileira para o Progresso da Ciência (SBPC), Sociedade de Estudos e Atividades Filosóficas (SEAF), Confederação de Professores do Brasil (CPB), Centro de Estudos Educação e Sociedade (CEDES), Confederação Geral de Trabalhadores (CGT), Central Única de Trabalhadores (CUT), Federação Nacional dos Orientadores Educacionais (FENOE), Federação das Associações dos Servidores das Universidades Brasileiras (FASUBRA), Ordem dos Advogados do Brasil (OAB ), União Brasileira de Estudantes Secundaristas (UBES ), União Nacional dos Estudantes (UNE).

9 BARRETO, E. B. S. Fato: IV Conferencia Brasileira de Educação. Revista ANDE, ano 6, n. 12. 1987.

10 CARTA DE GOIÂNIA. IV Conferência Brasileira de Educação, realizada de 02 a 05 de setembro de 1986. Disponível em: http://www.floboneto.pro.br/ pdf/outrosdoc/cartadegoi\%C3\%A2nia1986 4cbe.pdf Acesso em 06 mar. 2019.

11 PRESIDÊNCIA DA REPÚBLICA. Constituição da República Federativa do Brasil de 1988. Disponível em: http://www.planalto.gov.br/ccivil 03/Constituicao/Constituicao.htm Acesso em 06 mar.2019.

12 CÂMERA DOS DEPUTADOS. Lei no 4.024, de 20 de dezembro de 1961. Disponível em https://www2.camara.leg.br/legin/fed/lei/1960-1969/lei-4024-20-dezembro-1961-353722-publicacaooriginal-1-pl.html Acesso em 07 mar.2019.

13 PRESIDÊNCIA DA REPÚBLICA. Lei no 9.394, de 20 de dezembro de 1996. Disponível em http://www.planalto.gov.br/ccivil 03/leis/19394.htm Acesso em 21 abr. 2019.

14 PRESIDÊNCIA DA REPÚBLICA. Lei no 9.394, de 20 de dezembro de 1996. Disponível em: http://www.planalto.gov.br/ccivil 03/Leis/L9394.htm Acesso em 06 mar. 2019.

15 MINISTÉRIO DA EDUCAÇÃO. Resolução CNE/CEB no 4, de 13 de julho de 2010. Disponível em: http://www.crmariocovas.sp.gov.br/Downloads/ccs/concurso 2013/PDFs/resol federal 04 14.pdf Acesso em 05 abr.2019.

16 SUPREMO TRIBUNAL FEDERAL. Ação Direta de Inconstitucionalidade 4439. Publicada em 27 set. 2017. Disponível em http://www.stf.jus.br/portal/cms/verNoticiaDetalhe.asp?idConteudo=357099 Acesso em 08 abr. 2019.

17 PRESIDÊNCIA DA REPÚBLICA. Lei no 13.005, de 25 de junho de 2014 Disponível em: http://www.planalto.gov.br/CCIVIL 03/ Ato2011-2014/2014/Lei/L13005.htm Acesso em 05 abr. 2019.

18 MINISTÉRIO DA EDUCAÇÃO. Disponível em: http://historiadabncc.mec.gov.br/documentos/BNCCAPRESENTACAO.pdf Acesso em 05 abr. 2019.

19 MINISTÉRIO DA EDUCAÇÃO. Disponível em: http://historiadabncc.mec.gov.br/documentos/bncc-2versao.revista.pdf Acesso em 05 abr. 2019.

${ }^{20}$ MINISTÉRIO DA EDUCAÇÃO. Portaria no 790, de 27 de julho de 2016. Disponível em http://portal.mec.gov.br/index.php?option $=$ com docman\&view $=$ download\&alias=46471-link-port-790-base-curricularpdf\&category slug=julho-2016-pdf\&Itemid=30192 Acesso em 05 abr. 2019.

21 SILVA, Marcelo Lira. Coup d’État e exclusivismo político-educacional: uma análise da Medida Provisória 746/2016. In. Germinal: Marxismo e Educação em Debate, Salvador, v. 9, n. 3, p. 182-210, dez. 2017. Disponível em https://portalseer.ufba.br/index.php/revistagerminal/article/view/23726/15289 Acesso em 21 abr. 2019.

22 G1. Processo de impeachment é aberto e Dilma é afastada por até 180 dias. Publicado em 12 mai. 2016. Disponível em http://g1.globo.com/politica/processo-de-impeachment-de-dilma/noticia/2016/05/processo-de-impeachment-e-aberto-edilma-e-afastada-por-ate-180-dias.html Acesso em 05 abr. 2019.

${ }^{23}$ MORENO, Ana Carolina; MARQUES, Marília. Após revogar indicações feitas por Dilma, Temer nomeia membros do Conselho Nacional de Educação com seis meses de antecedência. In. G1. Publicado em 04 abr. 2018. Disponível em https://g1.globo.com/educacao/noticia/apos-revogar-indicacoes-feitas-por-dilma-temer-nomeia-membros-do-conselhonacional-de-educacao-com-seis-meses-de-antecedencia.ghtml Acesso em 05 abr. 2019.

${ }^{24}$ MORENO, Ana Carolina. Após protesto, audiência pública sobre a Base Nacional Comum Curricular do ensino médio é cancelada em São Paulo. In. G1. Publicada em 09 jun. 2018. Disponível em https://g1.globo.com/educacao/noticia/aposprotesto-audiencia-publica-sobre-a-base-nacional-curricular-do-ensino-medio-e-cancelada-em-sao-paulo.ghtml Acesso em 05 abr. 2019 .

25 GUIA DE IMPLEMENTAÇÃO BNCC. Disponível em https://implementacaobncc.com.br/ Acesso em 05 abr. 2019.

${ }^{26}$ MINISTÉRIO DA EDUCAÇÃO. Parecer CNE/CP nº15, de 15 de dezembro de 2017. Disponível em http://portal.mec.gov.br/index.php?option $=$ com docman\&view $=$ download\&alias $=78631$-pcp015-17pdf\&category slug=dezembro-2017-pdf\&Itemid=30192 Acesso em 05 abr. 2019.

27 MINISTÉRIO DA EDUCAÇ̃̃O. Base Nacional Comum Curricular: Ensino Infantil e Fundamental. Disponível em http://portal.mec.gov.br/index.php?option $=$ com docman\&view $=$ download\&alias $=79611$-anexo-texto-bncc-aprovado-em-1512-17-pdf\&category slug=dezembro-2017-pdf\&Itemid=30192 Acesso em 05 abr. 2019.

28 MINISTÉRIO DA EDUCAÇÃO. Diretrizes Curriculares Nacionais (PCNs). Resolução no 03, de 21 de novembro de 2018. Disponível em http://novoensinomedio.mec.gov.br/resources/downloads/pdf/dcnem.pdf Acesso em 07 abr. 2019.

${ }^{29}$ COMMON CORE STATE STANDARDS http://www.corestandards.org/ Acesso em 13 mar. 2019.

30 MOVIMENTO PELA BASE NACIONAL COMUM. Disponível em http://movimentopelabase.org.br/quem-somos/ Acesso em 13 mar. 2019.

31 MOVIMENTO PELA BASE NACIONAL COMUM. Disponível em http://movimentopelabase.org.br/quem-somos/ Acesso em 13 mar. 2019.

32 INSTITUTO AYRTON SENNA. Disponível em https://institutoayrtonsenna.org.br/pt-br.html Acesso em 08 abr. 2019. 
33 CAFARDO, Renata. Bancada Evangélica reage a nome de Mozart Neves para o Ministério da Educação. Publicado em 21 nov. 2018. Disponível em https://educacao.estadao.com.br/blogs/blog-renata-cafardo/mozart-neves-sera-o-ministro-de-educacaode-bolsonaro/ Acesso em 13 mar. 2019.

34 MATOSO, Filipe; GARCIA, Gustavo. Bolsonaro anuncia Ricardo Vélez Rodríguez como ministro da educação. Publicado em 22 nov. 2018. Disponível em https://g1.globo.com/politica/noticia/2018/11/22/bolsonaro-anuncia-ricardo-velez-rodriguezcomo-ministro-da-educacao.ghtml Acesso em 13 mar. 2019.

35 GARCIA, Gustavo; CALGARO, Fernanda; MATOSO, Filipe; LIS, Laís; e, RODRIGUES, Mateus. Senado aprova impeachment, Dilma perde o mandato e Temer assume. In. G1. Publicado em 31 ago.2016. Disponível em http://g1.globo.com/politica/processo-de-impeachment-de-dilma/noticia/2016/08/senado-aprova-impeachmentdilma-perde-mandato-e-temer-assume.html Acesso em 22 fev.1019.

${ }^{36}$ CAMPOS, Ana Cristina. Ensino Básico tem 73,5\% dos alunos em escolas públicas, diz IBGE. In. Agência Brasil. Publicado em 21 dez. 2017. Disponível em: http://agenciabrasil.ebc.com.br/educacao/noticia/2017-12/ensino-basico-tem-735-dos-alunosem-escolas-publicas-diz-ibge Acesso em 18 fev.2019.

37 TOKARNIA, Mariana. Mais de mil escolas no país estão ocupadas em protesto; entenda o movimento. In. Agencia Brasil. Publicado em 25 out. 2016. Disponível em: http://agenciabrasil.ebc.com.br/educacao/noticia/2016-10/mais-de-mil-escolasdo-pais-estao-ocupadas-em-protesto-entenda-o-movimento Acesso em 13 fev. 2019.

38 MINISTÉRIO DA EDUCAÇÃO. Novo ensino médio 01 e 02. Publicado em 06 jun. 2017. Disponível em https://youtu.be/iIszj0WWqfA e https://youtu.be/4pb1 nasqUtQ Acesso em 08 abr. 2019.

39 SILVA, Marcelo Lira. Ensaio sobre a função social dos partidos na contemporaneidade e o papel dos intelectuais. In. ORG \& DEMO, Marília, v. 18, n. 1, p. 129-140, Jan./Jun., 2017. Disponível em file:///C:/Users/Marcelo\%20Lira/Downloads/7447Texto\%20do\%20artigo-23918-1-10-20171108\%20(2).pdf Acesso em 21 abr. 2019.

40 G1. Bolsonaro demite Vélez e nomeia Abraham Weintraub como ministro da educação. Publicado em 08 abr. 2019. Disponível em https://g1.globo.com/politica/noticia/2019/04/08/planalto-anuncia-demissao-de-ricardo-velez-rodriguez-do-ministerioda-educacao.ghtml Acesso em 21 abr. 2019.

${ }^{41}$ OLIVEIRA, Elida. Abraham Weintraub: saiba quem é o novo ministro da educação. Publicada em 08 abr. 2019. Disponível em https://g1.globo.com/educacao/noticia/2019/04/08/abraham-weintraub-saiba-quem-e-o-novo-ministro-da-educacao.ghtml Acesso em 21 abr. 2019. 